\title{
Literature in the Irish Diaspora: The New Zealand Case, 1873-1918
}

KEVIN MOLLOY

Victoria University of Wellington

In surveying the cultural history of the Irish in New Zealand it is apparent that from the beginnings of their settlement in this country the Irish sought social, cultural and political self-definition through a range of Irish literatures - literatures from their land of origin, and literatures from the greater nineteenth-century Irish diaspora in North America, Australia, England, Scotland, New Zealand and Argentina. ${ }^{1}$ This literature generally came in two formats, printed volumes of history, fiction, poetry, oratory, music and songs, and the Irish or Irish-Catholic newspaper that, more often than not, carried its own range of history, fiction, poetry, oratory and music as partand-parcel of its regular social and political journalism.

In 1875, two years after the New Zealand Tablet was established, the paper ran a story on the international newspaper press, identifying the names, origin, and dates established of ninety-five current Irish papers in America and Canada alone. ${ }^{2}$ What was important in this article, and others of a similar ilk, is the representation of a comprehensive network, an enterprise in which all Irish, no matter where they were situated, were participants. ${ }^{3}$ For the Irish in this post-Great Famine period, the latter half of the nineteenth-century was the age of cultural affirmation and rebuilding. Like many pre-twentieth-century programmes, this cultural rebuilding started as a communication strategy, essentially a newspaper-led programme that branched into the book trade. ${ }^{4}$ In America, where the newspaper had, by the end of the nineteenth century, assumed almost mythic status as a form of indigenous literature, it created an unprecedented cultural homogeneity, and when this was combined with literature from local Irish-American publishing houses the growth, coherence and bonding of Irish communities there and around the Pacific and Atlantic trading routes was ensured. ${ }^{5}$

In Ireland this cultural and political revival was led by writers and newspaper journalists Thomas Davis, John Mitchel and Alexander Sullivan, scholars such as John O'Donovan and Eugene O'Curry, cultural critics and writers Samuel Ferguson and (later) W.B. Yeats, and political and social leaders Michael Davitt, Charles Stewart Parnell and John Redmond. Figures like the liberal British Prime Minister William Gladstone supported it 
in its Home Rule aspect fervently, while at the other extreme it became coupled to a Catholic devotional revolution in Ireland and an Irish Catholic internationalism promulgated by a powerful Catholic Church politburo led from Rome and then Dublin by Cardinal Paul Cullen and his many clerical followers. ${ }^{6}$ This latter aspect, one that placed more emphasis on the 'destiny' of the Irish and their Catholic Church, saw the spread of an international English language devotional, historical and theological literature, that, from the mid-1850s to the mid-1870s, began to assume a powerful presence in the book lists published in papers like the Sydney Freeman's Journal and the New Zealand Tablet. Therefore, in addition to a cultural and ethnic definition provided by secular literatures, the Irish also sought definition through a variety of religious literatures in English. Generally these were imported in tandem with secular literatures, and were often produced by the same publishing companies. ${ }^{7}$ The impact and influence of nineteenth-century religious literatures upon Irish immigrants constitutes a major component in an overall understanding of ethnic formation. This process has not been investigated in a New Zealand-Irish context, and though it will be touched upon in the following pages, it is beyond the scope of the present study. ${ }^{8}$

This paper will survey a number of issues arising from the importation of a literature by and for an ethnic minority in New Zealand. It will suggest definitions of that literature, probe what was being imported, consider the debate surrounding the need for an Irish and Catholic literature in New Zealand, and include observations on the works of those Irish and Irish-American writers that were popular with this ethnic clientele. From preliminary research it appears that a number of key primary sources for such a study - business records, the printed annual shop catalogues and registered company records - are no longer extant. ${ }^{9}$ Some additional information has been garnered from publishing records in the United States, Australia, England and Ireland, the sources from which the New Zealand booksellers imported. ${ }^{10}$ For example, a small number of nineteenth-century catalogues have been identified and utilised. Nevertheless, it appears many other records have, over the decades, been neglected or discarded. Others have shared the fate of the Ward, Lock and Co. business records that perished in the London Blitz of 1940. ${ }^{11}$

Print historian Wallace Kirsop has noted the primary role newspapers play in the study of book history, due largely to the non-survival of many primary records from the print culture industry. ${ }^{12}$ This certainly has been the case when attempting to reconstruct the business of importing and selling Irish literature in New Zealand. Data for this paper is based on author and title lists gleaned from the New Zealand Tablet over the period $1873-1918 .{ }^{13}$ Other newspapers were checked for similar advertisements, but the inconsistency of advertising, or the short-lived nature of many newspapers, yielded 
limited results. By and large, other newspaper advertising confirmed the popularity of works listed in the New Zealand Tablet and suggested similar titles. ${ }^{14}$ Usefully, the New Zealand Tablet was a national medium, taking in advertisements from centres as far afield as Auckland and Dunedin, and later Sydney and Melbourne. Its national coverage can therefore be taken as representative of market-place trends in Irish book retailing for the period under consideration. Other newspapers nevertheless add substantial information to the study of serialised Irish fiction in New Zealand. Deserving of an in-depth study in its own right, this topic is also beyond the scope of the present paper.

The literature categories for data analysis employed in this paper are based on those used in surviving nineteenth-century book catalogues and terms found in contemporary New Zealand book list advertisements. For example, standard nineteenth-century subject descriptors used by retailers when advertising in the New Zealand Tablet include 'History', 'Poetry', 'Travel', 'Oratory', 'Music', 'Memoir' and 'Biography'. The term fiction is not employed though the word 'Tale' is. For the purposes of this study fiction covers both tales and folk tales. Other categories, for example 'Criticism', have been imposed on the data as the most convenient way of grouping that genre, always bearing in mind that in the late nineteenth century the art of critical analysis and evaluation was itself a defined genre, and that there were review magazines, for example the Dublin University Review, Quarterly Review and Edinburgh Review. ${ }^{15}$ The titles used in this study are those extrapolated from advertisements placed by Irish or Catholic booksellers in Dunedin, Christchurch, Wellington and Auckland, over the fifty-year period 1870-1920. ${ }^{16}$ These are author/title listed in the Appendix, by genre. Attempting to correlate the importation and retailing of titles for some genres with political or cultural activity in Ireland is a necessary aspect of any study of this kind. It therefore takes into account the significance of the impact of political and social events, such as the rise of Parnell and the Irish Parliamentary Party, or social and class preferences in the sale of literature. For example, based on nineteenth-century Irish New York publishing precedent, it has been suggested that certain nineteenth-century Irish titles appealed to the agricultural and manual labouring classes more than others. This paper will explore whether this can be substantiated for the New Zealand-Irish experience. ${ }^{17}$

As nearly all of the literature focused upon by this study is in the English language, it is important to be clear just what is being discussed, and the titles and genres that have been identified. Like all English-language literatures, definitions are fraught, and allegiances fluid. This was not seen as a major problem until the late nineteenth century, when the rise in scholarly Irish language textual criticism queried the nature of Irish literature 
written in English, and its definition according to an over-simplified Irish subject matter, non-Irish subject matter dichotomy. ${ }^{18}$ Cultural critic and poet William Butler Yeats addressed this issue in some detail, although there is no evidence of his essays finding their way into the pages of the New Zealand Tablet. ${ }^{19}$ However, later definitions of Irish literature have become more inclusive, and are not necessarily Irish subject matter dependent, accepting that fifteen hundred years of literature written in Irish, one thousand years in Latin, four hundred of English, and several hundred in Hiberno-Norman and Hiberno-English, can be considered part-and-parcel of a singular, contiguous, Irish cultural experience. ${ }^{20}$ From evidence in the Irish-Catholic newspapers in New Zealand, diaspora literature - American, Canadian, Australian, English - was seen as both inclusively Irish (i.e. not exclusively subject driven), and Catholic (but not exclusively so). The definition of writing is in keeping with parameters set by Stephen J. Brown's annotated bibliography of seventeen hundred works, Ireland in Fiction (1919), in which his stated aim was to include 'all works of fiction published in volume form, and dealing with Ireland or with the Irish abroad'. ${ }^{21}$

The interchangeable labels for Irish literature in the nineteenth century, Irish fiction being subsumed in some advertisements under 'Catholic Tales', have been addressed by a number of critics. In post-Famine Ireland, after the ethnic definition provided by the Irish language rapidly broke down, Irish and Catholic increasingly become synonymous - you are Irish not because you speak Irish but because you are Catholic. The cultural and ethnic mechanisms promoting this are beyond the scope of the present paper, but the result was the marginalisation of many other components of the Irish cultural experience, including the Anglo-Irish, Ulster Presbyterian, secular and left-wing anti-clerical elements in Irish life. ${ }^{22}$ What became the 'Irish Ireland' philosophy, promulgated by individuals such as journalist and newspaper proprietor D.P. Moran, was 'increasingly prepared to view the Anglo-Irish Protestant world as simply the alien culture of a garrison society ... [and] insisted that Ireland's authentic cultural nationalist identity was unquestionably as a Gaelic and Catholic nation, in which the AngloIrish, English-speaking Protestant could have no part'. ${ }^{23}$ There were many unfortunate consequences of the political promotion of the 'Irish-Ireland' idea which, though tangential to the present study, includes the filtering out, for New Zealand Irish-Catholic audiences, of Irish literature deemed to transgress posited cultural, social and religious mores. Thus the apparent exclusion of works like Emily Lawless' Hurrish: A Study (1886), and Gerald O'Donovan's Father Ralph (1913), excellent period novels displaying the Irish in a very unflattering light. ${ }^{24}$ Similarly, Irish histories by writers like J.A. Froude, or works by cultural critics like Michael McCarthy, for instance his Priests and People of Ireland, were also proscribed. ${ }^{25}$ In New 
Zealand Thomas Bracken, throughout his public-speaking career promoting Irish literature, consistently challenged the 'Irish-Ireland' philosophy, endeavouring to present Protestant and Catholic Ireland, and their literatures, as essential dual components of a single cultural nation. ${ }^{26}$

As previously noted, given the dearth of surviving business records, this study focuses on book-title and author-list advertisements placed by booksellers specialising in Irish and Catholic goods. Advertisements were systematically scanned for new titles, new shipments, or any alteration in style. In most cases bookshop advertisements ran for months, only changing when new shipments arrived, or new titles became available. It must be stressed that this study is based on title and author frequency, not bookshop advertisement frequency. The aim has been to ascertain what was being imported, in what years, and then to plot any significant changes detected. Over the fifty-year period, approximately 491 Irish and diaspora Irish listings have been identified. For data collection purposes these have been recorded by year of first appearance, and by subsequent yearly appearances. For statistical convenience this data has been grouped in five-year ranges, enabling the figures to be graphed over the 1870-1920 period.

Occasionally substantially different editions of similar works have been encountered, and, while not numerous, these have been registered as separate entries. For example, there were many and varied editions of the works of Thomas Moore and the speeches of Daniel O'Connell, including cheap and gilt cloth well-bound editions. Variations in price and quality are significant, often indicating quite new editions of an author's work from an Irish, American or British publishing house. ${ }^{27}$ In addition, many advertisements fail to supply a particular title, simply stating, for example, 'works by Mitchel', or 'works by M'Gee'. These have been registered as a single entry, under history if by historians, or fiction if fiction writers. Speeches by eighteenth- and nineteenth-century politicians also present problems, often being listed simply as 'speeches by Curran', 'speeches by Shiel', with no further editor or publisher identification. These too have been registered as single title entries. Typographical errors were numerous, occasionally resulting in completely erroneous titles. Further, there was a penchant for changing titles, or listing by the titles by which works were popularly referred, or by secondary titles. Much nineteenth-century fiction had extended titles and these were often abbreviated. For example, the Black Pedlar of Galway, published by Michael Kavanagh in 1867, is always referred to as the Black Pedlar, never by its correct title Shemus Dhu; the Black Pedlar of Galway. ${ }^{28}$ Where possible, all titles have been checked against a variety of literary, bibliographic and database sources. ${ }^{29}$

From the title and author lists, the 491 identified works fall into a number of recognisable genres: history, fiction, biography, language, music, oratory, 
poetry, memoir, criticism and a miscellaneous other category. The percentage breakdown (Fig.1) is based on the number of first-advertised individual titles, identified by genre in bookshop advertisements between 1873 and 1918 . The statistics indicate that the bulk of new Irish works imported fall into the fiction and history categories, 31 per cent and 29 per cent respectively, followed next by biography at 9 per cent, music 7 per cent, and then poetry at 6 per cent, language 5 per cent and oratory 3 per cent. The category for 'other' literature covers a broad spectrum, including autobiography, almanacs, directories, hagiography, geography, reference, pictorial, photographic works and travel. While the subject and genre headings below have been taken from standard nineteenth-century advertisements describing types of books imported, the category for 'other' literature is a delimitation I have imposed on literature not otherwise easily identified by subject in the newspaper advertisements.

\section{Literature by Genre, New Zealand Tablet 1873-1918}
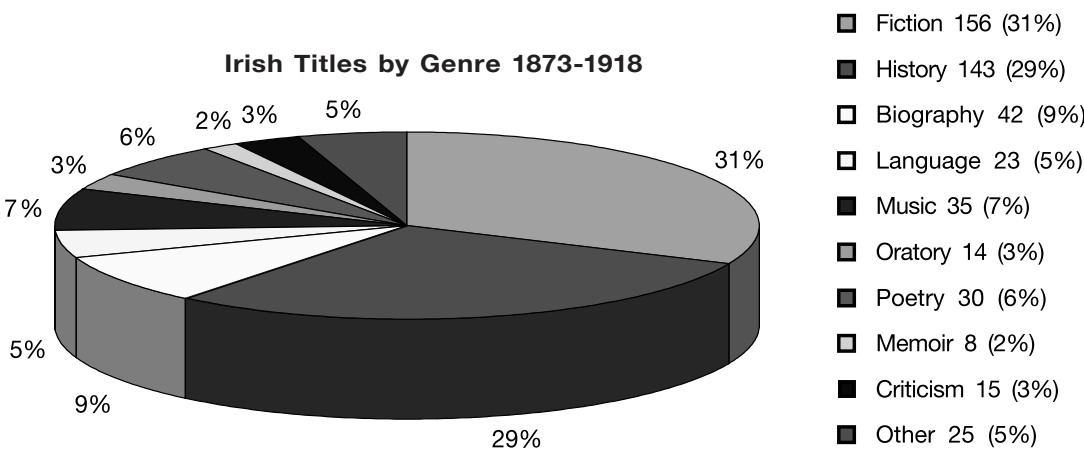

Figure 1 - Percentage breakdown over the period under consideration based on the identification of individual titles $(\mathrm{N}=491)$, and grouped by genre.

In terms of nineteenth-century British subject publishing, what do these figures suggest? In essence, the figures represent both new titles advertised in the retail market and current titles advertised over a number of years. Subject publishing figures in Britain for the same years, extracted from the Bibliotheca Londinensis and Publishers' Circulars, demonstrate the rise in popularity of fiction from the $1850 \mathrm{~s}$, together with the decline in religions works as the predominant subject category. ${ }^{30}$ Between 1890-1910 secular literature commanded over 30 per cent of the Circular's listing. The New Zealand figures collected for Irish literature tend to confirm the rise in demand for fiction, the increasing percentage of advertising space given over to new fiction titles, and the popularity of on-going fiction titles in its niche market. 
Fig.2 records the initial and subsequent advertisements for identified titles by percentage. Some differences are apparent. For example, while individual titles for oratory are low (14), advertising for this small number of titles is comparatively very high, indicating enduring popularity and consistent availability over subsequent decades. This is further evidenced in Fig.3, which directly compares title and advertising, according to number and genre. In terms of advertising numbers, it should be noted that the figures largely mirror the popular genre categories. However, while British figures for the decades indicate a decline in the combined history, geography, travel and biography market, collected statistics from the New Zealand Tablet indicate that historical titles retained around a 30 per cent share of the New Zealand-Irish advertising market. This feature of the Irish market, the continuing interest in historical titles, requires some explanation, being closely linked to cultural trends in nineteenth-century England. Cultural critic George Watson maintains that in the Victorian era, of which Ireland and New Zealand are tangentially part, there was no clear demarcation, in terms of shared social knowledge, between books on history per se and novels. ${ }^{31}$ This has obvious implications when assessing the large number of Irish historical works retailed or run as serials in the various New Zealand Irish-Catholic newspapers.

Initial and Subsequent Title Advertisements 1873-1918

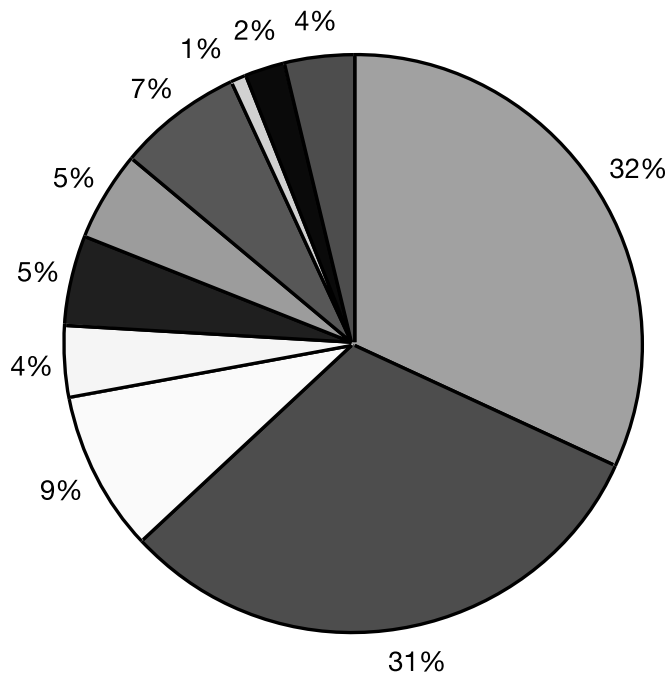

Fiction $223(32 \%)$

History 219 (31\%)

Biography 66 (9\%)

Language $30(4 \%)$

Music $45(5 \%)$

Oratory $45(5 \%)$

口 Poetry 50 (7\%)

Memoir $9(1 \%)$

Criticism 18 (2\%)

Other $28(4 \%)$

$31 \%$

Figure 2 - Advertised titles by genre, 1873-1918 period. 
Of the 1700 Irish works of fiction annotated by Stephen J. Brown for the period c.1700-1919, 12 per cent were estimated to be historical novels. Cahalan, using a narrower definition, estimates 7 per cent. ${ }^{32}$ This trend in Irish and Irish diaspora writing has also been noted by Charles Fanning, and is evident in the serialised fiction in the New Zealand Tablet and the New Zealand Freeman's Journal, examples being stories of the 1798 Irish Rebellion, and the wars by the O'Neills of Ulster. ${ }^{33}$

\section{Title and Advertising Numbers 1873-1918}

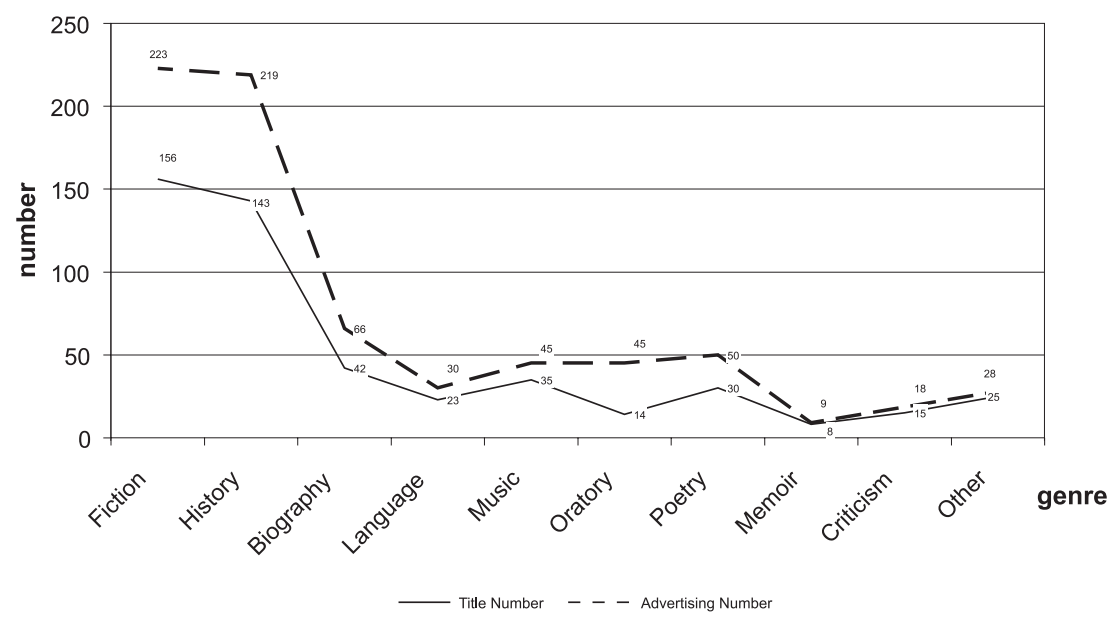

Figure 3 - New titles (bottom), and on-going title advertising (top), based on the first appearance of individual titles, and subsequent appearance in advertisements 1873-1918.

Much of the writing produced by the American-Irish world was tailored to the post-Famine generation of Irish immigrants. Fanning describes this literature as:

didactic and utilitarian . . . with three main purposes: Catholic-tract fiction to exhort the immigrants to keep the faith on alien soil, immigrantguidebook fiction to instruct the newly arrived on how to get along in America, and nationalist-political fiction to aid the cause of freedom from British rule . . . in Ireland. Often the three aims were addressed by a single author, and occasionally within a single novel. ${ }^{34}$

The prevalence of the historical-novel and historical works as popular consumer items for the nineteenth-century Irish population in New Zealand is in keeping with the promotion of a political-cultural nationalism among the Irish. Given the persistence of Irish-American content in the New Zealand 
Tablet, plus commentary on events and personalities in Irish-American communities, this should not surprise. ${ }^{35}$ Specific examples of historicalpolitical works include books by John Boyce, such as The Spaewife; or, the Queen's Secret. A Story of the Reign of Elizabeth (1853), David Power Conyngham's, Rose Parnell, or the Flower of Avondale: A Tale of the Rebellion of '98 (1883) and The O'Mahony, Chief of the Comeraghs: A Tale of the Rebellion of '98 (1879), Charles Halpine's, The Patriot Brothers, A Tale of '98 (c.1875), and Mary Anne Sadlier The Confederate Chieftains (1859) and The Fate of Father Sheehy (1845). Distant historical events, fictionalised, became or were used as rallying points for both politicising immigrants and giving them a sense of historical pride. The latter was all too absent in the grim realities not only of pre-Famine Ireland but also the post-Famine world of the 1850s and beyond. Poverty, emigration and violence remained vivid realities for many nineteenth-century Irish immigrants in New Zealand. From its inception in 1873 the New Zealand Tablet ran frequent articles relating to evictions, emigration, and the role of the British army in policing by force the Irish countryside. ${ }^{36}$ In general, the New Zealand Tablet derived its serialised fiction from a wide range of overseas printed sources, including Irish, American and English newspapers and journals such as Ave Maria (US), New York's Freeman's Journal, Dublin's Freeman's Journal, the Leinster Leader (Ireland), the Boston Pilot and the Pall Mall Budget (London). There is no clear evidence at this stage that the Irish-Catholic papers in New Zealand or Australia were using pre-printed circulating story pages for insertion in their newspapers. ${ }^{37}$

It appears that the role of biography, oratory and history was both didactic and political. The large number of eighteenth-century Irish oratorpoliticians retailed testifies not only to their popularity in Ireland but also throughout the Irish diaspora. The speeches of Grattan, Burke and Curran, and later O'Connell and Sheil, were available throughout the period under consideration, and it is easy to understand why. The oratory of the late eighteenth-century Irish parliament, before its demise, was renowned - articulate, positive, inspiring and nationalistic. Edmund Burke (1729-97), and Richard Lalor Sheil (1791-1851), made significant though very different political contributions to pre-and post-Famine Ireland, while O'Connell, besides being a fine orator, was the politician who pulled the country back from the brink of revolution in 1843-44. Perhaps for this reason - his political rejection of violence as a last resort - but also because he was a religious man, he was adopted as a model of the ideal Irish politician type in the columns of the New Zealand Tablet. ${ }^{38}$

The availability of popular biographies of the chief players in Irish history, and general histories of Ireland by narrative historians like McGee, Mitchel and Alexander Sullivan, all contributed to the national-cultural rebuilding 
that was under way through the latter half of the nineteenth century. In fact, the reading habits of the New Zealand-Irish appear not to greatly differ, except in the taste for fiction and its accessibility, from those of the Irish at home. The lengthy article by John Pope-Hennessey on the reading habits of the Irish in country towns, first published in the British periodical Nineteenth Century, and later reproduced in the New Zealand Tablet, confirmed an insatiable appetite for historical and political works. PopeHennessey (or his informant) had visited reading rooms in villages along the Cork and Waterford borders, initially set up by the Repeal movement and later run by the National League, and he gave a candid assessment of the literature he found there: histories by McGee, Duffy, Sullivan, McCarthy, O'Callaghan, Macaulay, Hallam, Froude, and Lecky; biographies of Tone, Grattan, Fitzgerald and the other United Irishmen. With the exception of the histories by Lecky and Froude, all these works were also available through the Irish-Catholic bookshops in New Zealand. ${ }^{39}$

It should be noted that the listing of literature in newspapers is a feature of the nineteenth-century journalistic world. The fashion altered after 1900, large book lists being no longer in evidence. In the years leading up to the First World War book title advertising further diminished, most advertisements being more discrete and giving notice of three or four new titles only. The early twentieth century is also the period when newspaper formatting changed from the densely packed eight- or ten-point type column inches to much larger script on a well-spaced page. Advertising style also altered, from text-based to the more spacious graphic-based advertisements. The consequence of these changes, combined with the general accessibility of catalogues, is that the collecting of data does not have the same cultural resonance after 1914 as before. In addition, although book reviews increase, there is little indication as to which bookseller may have submitted the title for review.

While the collecting of book titles up to the 1918 remains valid, the decreasing number of titles is not a true reflection of market-place activity. Nevertheless, in book trade 'archaeology', title collection is immensely valuable in terms of establishing what was being imported, and consumed, over what period, even if the ascertaining of numbers becomes less certain. For example, Figs. 1, 2 and 3 plot titles advertised in the New Zealand Tablet in five-year sequences over the decades of the greatest title advertising. Title advertising (Fig.4), suggests that considerable resources were utilised importing and advertising over key periods in late nineteenth-century Irish cultural and political history, specifically during the land wars (1879-82), the rise of the Irish Parliamentary Party under Parnell (1885-1891), with a further peak between 1900 and 1910 as the nationalist party (Irish parliamentary party) was rebuilt under John Redmond and Home Rule 
appeared to be imminent. ${ }^{40}$ Conversely, the data reveals the marked decrease in the advertising of Irish works after the fall of Parnell (1891). This possibly reflects the disillusionment of many colonial Irish with Irish national party faction-fighting, and, post 1910, the commitment by Redmond to a British war against Germany. ${ }^{41}$

\section{Peak title advertising in the New Zealand Tablet}

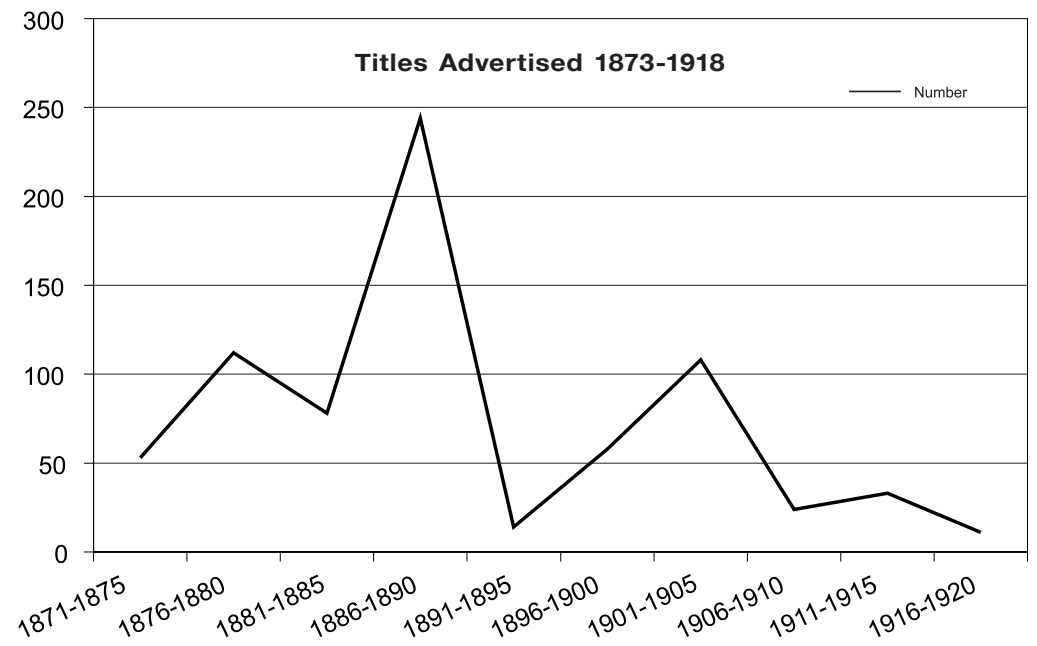

Figure 4 - Peak title advertising over the period 1873-1918

The apparent lack of demand for Irish literature in the early twentieth century may also be related to the evolving ethnic and demographic landscape in New Zealand and the natural process of acculturation, immigrant generations getting older and a younger generation of New Zealand Irish not inured to literature from an increasingly remote country. Articles in the Tablet at the turn of the century note two major issues: firstly, that too little was known of the works of Irish writers such as Goldsmith, Davis, Moore and O'Connell; and, secondly, the urgent need to foster an interest in Irish literature amongst the New Zealand-born Irish. ${ }^{42}$

It appears from comments in connection with the establishment of an Irish Literary Club in New Zealand that the Catholic Literary Societies were not engaging with Irish literature to any great degree, although individual members on occasion presented papers on Irish writers. ${ }^{43}$ When the New Zealand Tablet published an editorial calling for the establishing of a local Irish literary society it received at least one letter claiming there was a general lack of knowledge of the works of many of the Irish authors mentioned by the editorial writer. However, this seems at odds with what 
was being openly advertised in the Tablet, and what was available through the principal Irish booksellers. The call for an Irish literary society in the four main centres of New Zealand was arguably spurred by the realisation that a new generation was growing up in ignorance of the literature of Ireland. The writer called for a 'regular, systematic and critical study for the masterpieces of Irish literature' as an ongoing feature of the cultural life of the Irish in New Zealand. ${ }^{44} \mathrm{He}$ acknowledged the work of the Catholic Literary Societies in fostering some interest in Irish writers, but, in almost apologetic tones, admitted their knowledge of the subject was not adequate to this specialist task.

In hindsight, this nation-wide call for the study of the literature of a specific ethnic group would be one that today would be directed at tertiary level educational institutions. It marks a degree of cultural maturity, although masked in a language of patriotism and the memory of an older generation of Irish immigrants of the national life of Ireland. Unfortunately, there is no indication that such a club or literary society was ever established in New Zealand, although the Tablet endeavoured to sustain through its columns a high level of interest in Irish literature, both in the English and Irish languages. It reproduced the latest articles debating aspects of the literature of Ireland, even those questioning whether a national Irish literature written in English was really possible. ${ }^{45}$ In the 1890 s, at the request of one of its readers, the paper also introduced a 'Gaelic Notes' section. ${ }^{46}$

What then does the collected data reveal about the reading habits of the Irish in New Zealand over the fifty years under consideration? Certainly the book-title data adds substance to the extensive cultural discourse found in the New Zealand Irish-Catholic newspapers. As the Sydney Freeman's Journal had in the mid-1850s, the first editorial of the New Zealand Tablet in May 1873 tackled the problem of literature, the lack of suitable books, and the difficulty of procuring them in 'remote' New Zealand for an Irish and Catholic audience. ${ }^{47}$ The issue of literature, and its availability for Irish-Catholic immigrants, became one that was constantly debated. The Tablet saw a healthy Irish-Catholic presence amongst the fourth estate as both publicly and culturally filling a gap for a large section of the New Zealand community. It also viewed the newspaper as offsetting the lack of a suitable literature for the Irish community, presumably by engaging in those areas that would have traditionally been filled by a range of Irish-Catholic periodicals, newspapers and books. ${ }^{48}$

This intertwining of literature and the newspaper press, Irish ethnicity and Catholicism, began early in New Zealand Irish history, as a New Zealand Tablet editorial of 1876 makes clear:

In these colonies, most Catholics are either Irishmen or the children of Irish parents, and therefore the credit of the Irish name is, or ought to 
be, of importance to them . . . .The Journals that openly inveigh against the Church inveigh as openly against the Irish race; and the journals that more meanly hint objections against the Church, with like meanness contrive at least to ridicule the people of Ireland . . . . The Catholic press alone is the friend of the Irishman. In its columns only does he meet with justice and due appreciation, and here alone does he find his nation fitly estimated, its trials considered, and its interests advocated. ${ }^{49}$

To further the social and cultural programme implicit in this statement, the paper introduced informed debate on a range of issues, including a critique of Irish literature. This ranged from reviews of the poetry of James Clarence Mangan and others, either taken from papers like the Boston Pilot or written specifically for the Tablet, detailed accounts of public lectures on Irish writers such as Samuel Lover and Charles Lever, the printing of articles on a national literature, and analysis and evaluation of the various historians of Ireland. ${ }^{50}$ What is not present, however, is a tradition of reviewing new authors. For example, there do not appear to have been any book reviews of the works of Mary Anne Sadlier or Rosa Mulholland, or biographical profiles on these and other contemporary Irish and Irish-American writers. Possibly the readership knew the backgrounds of these authors, or gathered that information from other papers or articles in readily available sources like the American journal Catholic Home Annual. ${ }^{51}$

In tandem with its social and cultural programme, and reinforcing this agenda, the New Zealand Tablet from the early 1880s and the rise of Parnell carried and utilised the urgent national imperative tied to the programme of Home Rule. The language used set up binary oppositions that bound the 'Irish people at home and abroad', as the following address to the Irish people from the Irish National Land League, reprinted in the Tablet in 1881, makes clear, with its good versus evil, Irish versus English, the tillers of the soil with their families and dependents versus a privileged class supported by an English government:

Fellow-countrymen and friends - at a crisis of tremendous importance to our country, we confidently address ourselves to you. The British Government of Ireland, obeying the dictation of a privileged order of person, a cruel and selfish class, for centuries past the burden and curse of our land and people, have cast to the winds the tradition and principles of that liberalism to which they profess to be devoted, and have set in motion the legal power of the State and availed themselves of the resources at their command in the public revenue, to arraign at a criminal bar the chief man of the Irish race, and with him others of the most active and distinguished labourers in the cause of Ireland's social regeneration ... We therefore appeal to you ... . ${ }^{52}$ 
The imprisonment of Parnell and rise of the Land League and Irish Parliamentary Party lent great impetus to book buying in New Zealand, if the number of titles advertised over the $1880-1895$ period is any reliable indication. ${ }^{53}$ Nevertheless, despite the apparent availability of Irish writing through New Zealand Irish-Catholic outlets, and the critical discourse surrounding the available literature, the reality in some places appears to have been quite different. For example, the former premier of Victoria, Charles Gavan Duffy, after retiring to France from Australia, lamented the lack of Irish books both in Ireland and around the world: 'we want to have reproduced works which have disappeared out of circulation. The hundred best Irish books have been skilfully discussed in the newspapers, but the young student soon discovers that half of the hundred are out of print, or locked up from him in costly editions. Fifty pounds would not purchase the volumes recommended. ${ }^{54}$ This had obvious implications in nineteenth-century New Zealand, where the purchase of a well-bound book required the outlay of a substantial portion of the average weekly wage. ${ }^{55}$ Duffy goes on to discuss the book canvassing business in America, which brought books to the most remote farms, and the role of Irish booksellers in America and Australia, alluding to their facilitation of book distribution and how similar structures must be put in place in Ireland and expanded to other parts of the Irish immigrant world. ${ }^{56}$

Duffy's concerns echo those expressed five years earlier by P.E. Hurley in a discussion of the Irish in New Zealand in the Irish Ecclesiastical Record: 'The rising generation of this Colony is a reading people. There is hardly a district here corresponding in extent to an ordinary parish at home, that has not its two or three public libraries supplied with a variety of the current literature of the day'. Hurley lamented the lack of suitable Catholic literature in public libraries, and the extent of the anti-Catholic free-thinking literature generally available to all. He ended with an observation that runs through many of the discussions on literature: 'when they forget the land of their fathers the faith of their fathers vanishes too. When they cease to remember that they are descendants of heroes they begin to forget that they are the children of martyrs also . . . Let the Irish emigrant be warned of this, and let him be exhorted never to forget in a foreign land the home where his youth was nursed. ${ }^{57}$

Such rhetoric, though emotionally provocative, could be seen as simply a literary trope of the times. There is certainly considerable rhetorical posturing in the later nineteenth century by those in the Church hierarchy endeavouring to link the 'call to arms' in politics with that in religion, and harnessing it all to an Irish-Catholic internationalism. However, although the New Zealand Tablet published a number of key strictures on 'literature' in its columns, many relate solely to Ireland and are demonstrably tangential 
to the New Zealand situation. Knowledge of what exists in the market also varies. Gavan Duffy's call for access to cheap readily available editions of Irish literature seems at odds with the type of literature being produced by Irish and Irish-American publishers, editions widely available in New Zealand and Australia. While the provenance of some library editions is still unclear, certainly the relatively inexpensive Irish National Library series, produced by the publishing house of James Duffy \& Company, was imported extensively into New Zealand from the early 1870 s up to around 1900. After that date the Irish library series 'Denver's Monthly Irish Library' and 'Ousley's Irish Library' were retailed in New Zealand through the Australian Irish and Catholic booksellers William P. Linehan and Louis Gille. It is unclear at this stage just what percentage of Irish and Irish diaspora literature being imported into Australia was being on-sold to New Zealand..$^{58}$ Duffy's observations as to availability and cost require further investigation. What is evident is that all the above identified series of Irish works were retailed as relatively cheap discounted editions. In 1911 the ten-volume Irish Literature series was finally produced, its editor-in-chief being Justin McCarthy. ${ }^{59}$ It went at least some way towards alleviating the concerns identified by Duffy.

In an overview of the literature retailed and sold to Irish immigrants in New Zealand, the literature, as a consumer item, requires some analysis to determine exactly where it fits in the psycho-social drama of the life of the immigrant in the colonial world. Though it is difficult to accurately estimate the volume of Irish books imported into New Zealand over the 50 years studied, it is possible, from the data presented, to identify a significant number of retailed writers and titles according to title advertising numbers. In the case of fiction writers, examples include the works of William Carleton, Rosa Mulholland, and Mary Anne Sadlier; in respect of music and poetry, Thomas Moore; and for Irish history Alexander Sullivan, John Mitchel and Thomas D'Arcy McGee. While detailed critique of these writers, and an assessment of the importance of their works for the nineteenth-century Irish immigrant, is beyond the scope of the present study, some tentative observations as to how they contributed to the cultural milieu of the Irish in nineteenth-century New Zealand are possible.

In post-Famine Irish-American fiction a relatively small number of writers both dominate the scene and are representative of a generation of immigrants evolving and adapting in a new world environment. These include John Boyce and Hugh Quigley (both priests), Charles Halpine and David Power Conyngham (ex-Irish-American Civil War soldiers), Maurice Francis Egan (a university teacher of English), Finley Peter Dunne (journalist and newspaper proprietor), and Mary Anne Sadlier, also known as Mrs Sadlier (translator, publisher, journalist and newspaper editor).$^{60}$ Of the above, the works of 
Boyce, Conyngham, Halpine, Egan and Sadlier were readily available in the Irish-Catholic bookshops throughout New Zealand. ${ }^{61}$ An additional IrishAmerican novelist, poet and journalist Patrick Sarsfield Cassidy, founder of the New York Press Club, arrived in New Zealand in the 1890s, and was for some years manager of the New Zealand Times and Mail Publishing Company. Reviews of his work are occasionally found in the New Zealand Tablet. ${ }^{62}$

It was Irish emigrant Mary Anne Sadlier (nee Madden) who specialised in works on how to get on in the new world. Sadlier landed in Montreal in 1844, working as a domestic servant, and occasional writer, before marrying Catholic publisher James Sadlier in 1846. She initially managed the Montreal branch of the company before moving to New York. ${ }^{63}$ Kilroy has noted that Sadlier's work is of some interest as 'an indicator of what the unlearned, homesick Irishman (and Irish woman) was reading during the latter half of the nineteenth century ${ }^{6}{ }^{64}$ However, the texture and sociological impact of Sadlier's fiction is more complex than this observation suggests. Eleven of Sadlier's novels were imported into New Zealand and retailed over the period 1876-1896. These include The Fate of Father Sheehy (1845), Alice Riordan, the Blind Man's Daughter (1851), The Blakes and Flanagans (1855), The Confederate Chieftains (1859), Bessy Conway; or the Irish Girl in America (1861), The Hermit of the Rock (1863), Con O'Regan; or, Emigrant Life in the New World (1864), Simon Kerrigan; or Confessions of an Apostate, or Leaves from a Troubled Life (1864), Aunt Honors's Keepsake (1865), Elinor Preston; or, Scenes at Home and Abroad (1866), and Marueen Dhu, the Admiral's Daughter (1870).

Sadlier began her public career as a newspaper storywriter with the serialisation of two of her major novels by Patrick Donoghue's Boston Pilot in $1850 .{ }^{65}$ Many of her works were written for newspaper serialisation, and with the setting up of the New York Tablet by D.\& J. Sadlier and Company in 1857 she gained a ready outlet for her writing. Mary Anne Sadlier eventually became sole editor of the New York Tablet, for some years providing much of its copy. ${ }^{66}$ Sadlier's corpus of work conveys a range of quite complex messages. For instance, Bessy Conway, The Blakes and the Flanagans and Con O'Regan cover the lives of immigrants in the new world, with Con O'Regan considered by Fanning to be a major anti-emigration novel. ${ }^{67}$ A second group covers the historical nationalist themes, including works that range from the dark eighteenth-century patriotic novel The Fate of Father Sheehy, to the romantic and patriotic seventeenth-century novel, The Confederate Chieftains, dealing with the Irish leader Owen Roe O'Neill and the Gaelic Aristocracy. This novel appears to be the first by Sadlier to be serialised by a New Zealand newspaper, running in the New Zealand Freeman's Journal throughout 1880-81. It was still being recommended to New Zealand Irish readers by the Tablet in $1915 .{ }^{68}$ 
Sadlier's novels cover romantic, patriotic, national-cultural and religious themes, but also question much that is taken for granted. As Fanning has noted, while The Blakes and the Flanagans, a book encompassing lower middle-class Irish families in New York, highlights the importance of the Catholic education issue for Irish immigrants, it is also powerfully antiassimilationist. Sadlier's Irish, Catholic and conservative views were plainly at odds with the American (and presumably colonial) experience ${ }^{69}$ Similar themes are also present in the novel Con O'Regan. Sadlier's work has ultimately been characterised as providing 'survival guides for displaced immigrants in an often hostile environment', trying to take the best of both worlds, the Irish past and the new American future. ${ }^{70}$ As an Irish and Catholic literature of the new world, her works were an antidote to the romantic and often anti-Catholic literature of the time, a literature that both secular literate Catholics and the Church hierarchy were encouraging North American Irish writers to directly challenge. That Sadlier's work should have been popular with a New Zealand-Irish audience facing similar challenges, and with many of the same occupational demographics, is not at all unusual. ${ }^{71}$ For example, Fraser states that the number of Irish female domestic servants in towns like Christchurch was substantial, the domestic servant being considered a major occupational class, while Charlotte Macdonald has noted that single women 'were consistently the most rapidly absorbed section of the migrant population', and rarely lasted more than a week at immigration barracks such was the demand for domestic servants. ${ }^{72}$ While there is no direct evidence New Zealand-Irish domestic servants read Bessy Conway, it was a novel specifically written for this particular group of Irish female immigrants.

When looking at the works and popularity of William Carleton, several things set him apart from the generations of writers around him. Carleton is noted as being the first Irish novelist to write exclusively for an Irish audience, through the papers, penny journals and later the Dublin University Review. Unlike Maria Edgeworth, Charles Lever or Samuel Lover, such a favourite of New Zealand poet Thomas Bracken, Carleton was writing for an Irish and not an English audience. Hence the portraits of fiddlers and priests, drinkers, misers, faction fights, secret societies, poverty, starvation and famine. Carleton's dismissal of another Anglo-Irish novelist, Anna Hall, applies to many of the writers before him: 'did she ever live with the people as I did? Did she ever dance and fight with them as I did? Did she ever get drunk with them as I did? ${ }^{73}$ Carleton moved from the Irish-speaking world of Co. Tyrone to the largely English speaking culture of Dublin, changing his language, his religion and anglicising his name. One of fourteen children born to Irish peasants, he wrote only of the Irish peasant world he knew before he left it, and wrote only in English. Given Greene's comments 
relating to Carleton's appeal in the North American context to lower working class Irish immigrant, the popularity of his works to the colonial New Zealand Irish obviously merits a more detailed critical treatment. ${ }^{74}$ Research might include the examination of surviving lending library catalogues from locations such as the mining districts of Central Otago. ${ }^{75}$ The grim Irish peasant life portrayed by Carleton, although not without its comic elements, was radically different to the rollicking, humorous Irish type sketched by the Anglo-Irish writers Lover and Lever and promoted so assiduously in New Zealand by Thomas Bracken. ${ }^{76}$ Carleton's writings were also included in the General Assembly Library's 1899 catalogue of works, and additional nineteenth-century editions have found their way into the national collection. ${ }^{77}$

The New Zealand taste for Irish literature was, however, in keeping with other colonial trends. Thomas Moore appears to have appealed to a wide spectrum of the English-speaking population, not just to the Irish. As Fanning has noted, in America alone there were over twenty different editions of his work, and a title analysis of what was retailed by the IrishCatholic booksellers in New Zealand clearly indicates both his popularity among the New Zealand Irish and a great variety of editions, ranging from the most expensive gilt-edged volumes to the most inexpensive wrapper (paperback) versions. Moore's appeal in the nineteenth century seems to have cut across ethnic and social divides, and may in some part be due to the setting of many of his works to music, drawing-room songs being popular in the nineteenth-century world. Any future analysis of Moore's popularity in late nineteenth- and early twentieth-century New Zealand must take account of the advent of the upright parlour piano in colonial society.

The didactic nature of nineteenth-century Irish fiction has been noted in the writing of Sadlier and other Irish-American writers, and, while Carleton stands somewhat outside this literary tradition, it features prominently in works by Rosa Mulholland. Described as an intensely Catholic and nationalist writer, Mulholland began her career with a good deal of encouragement from Charles Dickens, an admirer of her work. ${ }^{78}$ Hogan acknowledges that she had some 'real knowledge of the peasantry' of the West of Ireland, but is of the view that that her work was overly romantic and religious, while Welch notes her standard Victorian version of Catholicism, and in later works her promotion of a Catholic gentry to solve the Irish land crises. ${ }^{79}$ In New Zealand Mulholland was endorsed by booksellers like Christchurch's Edward O'Connor as a standard Catholic writer, as was her English Catholic literary contemporary Georgiana Charlotte Fullerton, and both appear to have been retailed very successfully. There were nine Mulholland volumes available in New Zealand between 1886 and 1896, with editions by such 
publishers as Burns and Oats (London), M.H. Gill (Dublin) and Benziger Brothers (New York). ${ }^{80}$ That her works found their way into a recommended Catholic Library list before the First World War indicates perhaps the enduring Catholic quality of her work for a New Zealand audience, rather than its Irish subject matter. ${ }^{81}$

\section{Conclusion}

A number of features relating to the literature imported and made available in late nineteenth- and early twentieth-century New Zealand through booksellers specialising in the retailing of Irish works have been identified. That the retailing of Irish literature in New Zealand was part of an international retail trade is without doubt. By-and-large it appears the New Zealand Irish drew their literature from Irish and Irish diaspora sources, marketing that literature through both newspaper and catalogue advertising. In terms of literary tastes, the New Zealand-Irish market conformed to both an international English-speaking trend that witnessed an increasing preference for fiction, and an Irish preference for history and historical fiction. In New Zealand this is evidenced by the high retailing of works by historians Alexander Sullivan and John Mitchel, the enduring popularity of the speeches of political leader Daniel O'Connell and the eighteenth-century Irish Parliamentary orators, and the ongoing demand for fiction by Carleton, Mulholland, Sadlier and later Sheehan, amongst others. ${ }^{82}$

That the Irish, from the early stages of settlement, wished to 'develop' their own colonial identity, to maintain and disseminate their own literature, should be no surprise. As Fraser noted, 'ethnic identity . . . is a culturally constructed set of usages adopted by people in their day-to-day relationships with one another and the society around them . . . it is a contested choice, defined by people as they live their own history'. ${ }^{83}$ For Fraser, ethnicity and its apparel is not a given, it evolves from particular circumstances. Put another way, the Irish did not arrive in New Zealand armed with books.

In the cultural history of the Irish in New Zealand, the importation of the literature of Ireland, and the Irish diaspora, was both a choice made - to maintain contact with their land of origin, and reinforce shared cultural bonds amongst themselves and other displaced Irish communities - and the contested action of an ethnic minority living and culturally evolving in proximity to a numerically dominant 'other' culture, one with value systems, tastes and political and social allegiances quite often antithetical to the Irish and their community. ${ }^{84}$

Conducting a profitable importing and retailing business over decades requires a degree of business acumen, a product in demand, easy access to that product, sophisticated retail outlets, ready clientele, a good advertising medium, an efficient postal service, and, in the nineteenth century, regular 
trade routes for shipping. Available evidence suggests that booksellers operating in the Irish trade in New Zealand were able to rely on all of the above in marketing their specialised product. The fact that an Irish book trade sprang up over a relatively short period - with bookshops established, and importation and distribution trading patterns organised - suggests a certain flexibility in cultural movement and identity. The Irish in New Zealand easily assumed a cultural set of usages - the literature of their homeland and the Irish diaspora, and its existing networks, for self-definition - and just as easily left it as their history in New Zealand moved on ${ }^{85}$ By the early decades of the twentieth century this group, what GillespieNeedham has termed a subculture, had, in one aspect of its identity (literary taste), achieved a certain degree of homogeneity with the dominant culture (acculturation), retailing and reading far less Irish literature, as their tastes and literary predilections largely merged with those of the New Zealand Anglo-Saxon majority. ${ }^{86}$

The preceding analysis has attempted to determine the literary demands of the Irish in New Zealand and the social, cultural and political implications of those demands. The Irish-Catholic newspaper, the primary archival source available, is by-and-large a closed information system. The general needs of the immigrant population are not registered there in any representative, individualistic manner. The clerical representatives of the population endeavour to articulate some of their needs, but only in a mediated fashion. In short, there is never a clear immigrant voice. They are not interviewed by newspaper journalists at the docks upon arrival; nor coming out of the bookshops with their purchases. The booksellers themselves barely find a voice, except through their advertisements. There are no interviews or journal pieces like that in an 1859 issue of the Sydney Freeman's Journal reporting a lengthy conversation concerning literature between the editor of the Freeman's Journal and Mr E.F. Flanagan, an Irish bookshop owner. ${ }^{87}$ In addition, there are few published letters to the editor of the New Zealand Tablet in the early decades of the paper. Ultimately, the literary tastes of the clientele are currently known only from the tantalising inferences obtained from the preceding data. From that data it is clear that substantial numbers of Irish books were imported from Ireland, England, the United States and Australia, that the trade extended over decades, and that local and international networks were established to maintain the trade.

This paper has mapped out some of the complexities of late nineteenthand early twentieth-century Irish print history in New Zealand. The following Appendix is the start of a possible reconstruction of a catalogue of the books available to Irish and Catholic readers of secular literature. Additional research, such as an economic analysis of the book retailing figures, compared to the average weekly wage for identifiable occupational 
groups, and linked to a nineteenth-century consumer price index for New Zealand (CPI), would help in determining which particular income groups in New Zealand were capable of buying what books. ${ }^{88}$ This would also go some way towards tackling the currently impenetrable literacy figures for the Irish in nineteenth-century New Zealand ${ }^{89}$ While the present study has largely used the example of fiction as an area of the possible impact by print culture on the intellectual and social life of the Irish immigrant, with equal facility the role and impact of historical works, music, and religious literature could well be undertaken. From the list of works in the Appendix it is clear the range of Irish literatures imported and available in New Zealand for the immigrant Catholic Irish adds a complex hue to notions of Irish literacy, cultural development and intellectual curiosity.

1 An estimated 40-45,000 Irish settled in Argentina over the nineteenth century. In addition to the well known Irish newspaper, The Southern Cross, established in Buenos Aires in 1875, perhaps the most notable work produced in English by Irish Argentinians is William Bulfin's Tales of the Pampas (1900); see Edmundo Murray, 'How the Irish Became Gauchos Ingleses. Diasporic Models in Irish-Argentine Literature', http://www. irishargentine.org/ia_last.htm. [Accessed October 2004]. For literature on the Irish in South America see Brian McGinn, 'The Irish in South America. A Bibliography', http://www.brad.ac.uk/acad/diaspora/guides/samerica.shtml. [Accessed April 2003].

2 'The Newspaper Press', New Zealand Tablet, 13 February 1875, pp.9-10. The New Zealand Tablet hereafter also referred to as NZT.

3 For example, J. Pope Hennessy, 'What Do the Irish Read?', in NZT, 22 August 1884, pp.29-31, 29 August 1884, pp.25-27. This article was reproduced from the journal Nineteenth Century.

4 The newspaper played a formative role in the pre- and post-famine cultural and political development of Ireland and was discussed extensively by nineteenth-century Irish historians like William Lecky in his Leaders of Public Opinion in Ireland, London, 1871, p.xii, and is mentioned most recently by cultural historian Declan Kiberd in Irish Classics, London, 2000, p.464. Kiberd maintains that it was the willingness of Irish modernists to engage with newspapers, based on nineteenth-century precedent, that distinguishes them from their Continental colleagues.

5 For a discussion of the Pacific aspects of these networks see Malcolm Campbell, 'Ireland's Furthest Shores: Irish Settlement in Nineteenth-Century California and Eastern Australia', in Pacific Historical Review, vol.71, no.1, 2002, pp.59-90. Campbell states that 'California and eastern Australia, together with New Zealand, were, for much of the later nineteenth century, part of a Pacific Irish emigrant world - locations separated by the vast distances of the Pacific Ocean but unified by complex exchanges of peoples, information, and goods', p.62.

6 Donald Harman Akenson, Half the World from Home. Perspectives on the Irish in New Zealand 1860-1950, Wellington, 1990, pp.162-165. For a biographical study of Cullen and his influence on post-Famine Ireland see Desmond Bowen, Paul Cullen and the Shaping of Modern Irish Catholicism, Dublin, 1983; also Patrick O'Farrell, The Catholic Church and Community. An Australian History, Sydney, 1985. The term 'devotional revolution' was first used by American Irish historian Emmet Larkin to describe the complete change in peasant devotional practices in Ireland in the post-famine period (1850-1875), brought 
about by standardised, imported Catholic practices; see his 'The Devotional Revolution in Ireland 1850-1875', in American History Review, vol.77, 1972.

7 Publishers D. \& J. Sadlier and Co. (New York and Montreal), Benziger Brothers (New York), P.J. Kenedy (New York), Ward, Lock and Co. (London, and Melbourne from 1884), James Duffy and Co. and M.H. Gill (Dublin), all produced Irish and English secular fiction plus Catholic religious works. In addition there were Australian booksellers like Louis Gille \& Co. and W. P. Linehan who advertised imported religious and Irish works extensively in the New Zealand Tablet from the late 1890s. It should be noted that theological and pietistic works have not been included in the list of books provided in the Appendix, although books on Irish religious history and archaeology have.

8 Akenson's observations should be noted; see 'No Petty People. Pakeha History and the Historiography of the Irish Diaspora' in Lyndon Fraser, A Distant Shore. Irish Migration and New Zealand Settlement, Dunedin, 2000, pp.19-20. Catalogues are available for English language religious works from selected publishers, for example Benziger Brothers, Catalogue of all Catholic Books in English. Wholesale Catalogue for the Reverend Clergy and Religious Libraries, and the Trade, New York and Cincinnati, c.1912.

9 Checks have been made at the Alexander Turnbull Library, Archives New Zealand, the Hocken Library, Auckland Public Library and libraries in Christchurch.

10 For the United States a number of key New York publishers of cheap popular editions that were regularly imported into New Zealand are identified by David H Greene in 'Literary Interactions', The Irish Times, Literary Supplement, 15 March 1976. In addition, before the establishment of Whitaker Brothers' bookshop in Lambton Quay, the Catholic Archbishop of Wellington, Francis Redwood, was importing books directly for his own library from an Irish publisher in New York, Lawrence Kehoe, and from Burns and Oates, Paternoster Row, London; see Wellington Catholic Archdiocese Archive, Archbishop Redwood, Letterbook. Book One, 10 February 1875 - 23 August 1883, pp.291, 319, 320, 321.

11 Catalogues used include James Duffy \& Co., James Duffy \& Co.'s Catalogue of Standard Works of History Amusement and Instruction, Dublin, 1880, 1885, 1890, currently held by the Early Printed Books Library, Trinity College Dublin. An early publisher's catalogue for 1851 also exists, A Catalogue of Standard Catholic Works, and Books Relating to Ireland; Edward Living, Adventure in Publishing: The House of Ward Lock, 1854-1954, London, 1954, Introduction.

12 Wallace Kirsop, Books for Colonial Readers - The Nineteenth-Century Australian Experience, Melbourne, 1995, p.4.

13 Considering the newspaper as part of diaspora literature as well as a principal archival source requires some caution, and an awareness of the nature of the nineteenth-century print culture, advertising regimes, and newspaper business practice.

14 For example, Flynn \& O'Reilly's, and later J. O'Reilly's advertisements in the New Zealand Freeman's Journal (NZFJ) contain the same range of titles found in adverts in the Tablet by O'Connor, Whitaker and Macedo, NZFJ, 21 December 1883, p.1; 21 November 1884, p.1; 12 June 1885, p.1. Other New Zealand Irish papers consulted include New Zealand Celt (1867-1868) and The Catholic Times (1888-1894).

15 For an analysis of the role of the Reviews, see J.R. Tye, 'Literary Periodicals of the Eighteen Nineties: A Survey of The Monthly and Quarterly Magazines and Reviews', D.Phil. thesis, University of Oxford, 1970, p.5.

16 Booksellers used in this study include J.A. Macedo, who operated from Princes Street, Dunedin from approximately 1866-1897, retailing literature as a Catholic Bookseller from 1872; Edward O'Connor, whose Catholic Book Depot operated in Barbados Street, Christchurch, from 1880-c.1950s; Bernard and George Whitaker, operating as 
Whitaker Brothers, from Lambton Quay, Wellington from 1877-1917, and Cuba Street Wellington, managed by their sister Mary Gibbs, from c.1895-1900, with an additional branch in Boundary Street, Greymouth, operated by George from 1887. In Auckland, J.W. Dickson's 'Catholic Repository' operated from the late 1880s, and was preceded by James Flynn, Flynn and O'Reilly, and then just O'Reilly, from 1882-1885.

17 This observation was made by Greene; see D.H. Greene, 'Literary Interactions', Irish Times Supplement, 15 March 1976.

18 John MacNeill, 'What Ireland has Lost', in NZT, 11 June 1897, p.25. John MacNeill was editor of the Gaelic League's Gaelic Journal. This article raised some pertinent cultural issues that are still being debated over a century later.

19 See his extended essay on the Irish literary societies and other matters, 'Ireland after Parnell', in W.B. Yeats, Autobiographies, London, 1980, pp.199-250.

20 The five-volume Field Day Anthology of Irish Literature has become the compendium of Irish literatures - Irish, Latin, Hiberno-Norman, Hiberno-English, and English - and covers all genres on the cultural, social and political literary spectrum.

21 Stephen J. Brown, Ireland in Fiction: A Guide to Irish Novels, Tales, Romances and Folklore, Dublin, 1919, p.ix, 1915 Preface. Brown does list and comment upon works by Irish authors that are not specifically Irish subject-matter driven.

22 See John Hutchinson, The Dynamics of Cultural Nationalism. The Gaelic Revival and the Creation of the Irish Nation State, London and Boston, 1987. This subject is also mentioned by the author in, 'Victorian, Historians and Irish History. A Reading of the New Zealand Tablet, 1873-1903', in Brad Patterson (ed.), The Irish in New Zealand. Historical Contexts and Perspectives, Wellington, 2002.

23 Terence Brown, 'Cultural Nationalism 1880-1930', in Seamus Deane (ed.), The Field Day Anthology of Irish Literature, vol.2, Derry, 1991, p.517. D.P. Moran's most important essay expounding this view is titled 'The Battle of Two Civilisations'.

24 Writing in 1919 of the Anglo-Irish writer Lawless and her novel Hurrish, Stephen Brown described it in the following terms: "the "scene" is a wild and poverty-stricken district in Clare. A view of the bad days of the "eighties by one to whom the Land League stands for "lawlessness and crime". The people are depicted as half-savage. The story is a gloomy one, full of assassinations and the other dark doings of the Land League. The picture it gives of an Irish mother will jar harshly on the feelings of most Irishmen. The Irish dialect is all but a caricature'. Father Ralph on the other hand is the story of a defrocked priest who sets out to find his personal religion. The book is described as 'anti-clerical and modernist . . . . It may fairly be said that there is scarcely a page of this book that does not appeal in one form or another to non-Catholic prejudice'; see Brown, Ireland in Fiction, pp.162, 238. Neither work appeared in NZT advertised book lists, though they did appear in English Colonial Edition lists, so would have been readily available in New Zealand; see Johanson, A Study of Colonial Editions in Australia, 1843-1972, Wellington, 2000, pp.290-306. It should be noted that by 1915 Hurrish does appear in a recommended reading list of Irish books for Public Libraries, in NZT, 22 April 1915, p.43.

25 For some of the debate surrounding this work, and the questioning of McCarthy's Irishness because of this publication, see Heather McNamara, 'The Sole Organ of the Irish Race in New Zealand? A Social and Cultural history of the New Zealand Tablet and its Readers, 1898-1923', MA thesis, University of Auckland, 2002, p.53. It should be noted however that replies to McCarthy, by Cardinal Moran, and to Froude by Burke, are to be found in the book lists; see Appendix.

26 For example, see Bracken's lecture in Christchurch, August 1889, in which he discusses the common heritage of the Irish regardless of religious or political affiliations, NZT, 
8 August 1889, p.5. Bracken lectured extensively over the late nineteenth century, principally on the Irish novelists Samuel Lover and Charles Lever.

27 While this data has been collected, due to space considerations it has not been included in the Appendix. Price structure seems to have varied considerably, according to publishing house and the quality of the retailed product, with many different prices for the same volume. A more complex graph analysis plotting these changes according to the average New Zealand wage, over corresponding periods, is needed to bring out fully the importance of price and buying capacity of the client base. This is beyond the scope of the present work.

28 Browne, Ireland in Fiction, p.150.

29 Library of Congress Online Catalogue, http://catalog.loc.gov. [Accessed Jan-April 2003]; Trinity College Dublin Main Library and Early Printed Books Catalogues, http://opac. lib.tcd.ie. [Accessed Dec. 2002-April 2003]; the online British Library Public Catalogue, http://blpc.bl.uk [Accessed Nov-Dec. 2003]; State Library of Victoria Catalogue, http://catalogue.slv.vic.gov.au [Accessed Jan-April 2003]; National Library of Australia Catalogue, http://ilms.nla.gov.au. [Accessed Jan-April 2003]; Princess Grace Irish Library Datasets, Monaco, http://www.pgil-eirdata.org. [Accessed Dec 2002-April 2003]; National Library of New Zealand Catalogues, http://nlnzcat.natlib.govt.nz. [Accessed Dec 2002April 2003]; Stephen J. Brown, Ireland in Fiction, Dublin, 1919; Robert Hogan (ed.), Dictionary of Irish Literature A-L, M-Z, London, Connecticut, Westport, 1996; OCLC FirstSearch [Accessed 2003-04].

30 Simon Eliot, 'Some Trends in British Book Production, 1800-1919', in John O. Jordan and Robert L. Patten (eds), Literature in the Marketplace. Nineteenth-Century British Publishing and Reading Practices, Cambridge, 1995, pp.36-38.

31 George Watson, The English Ideology. Studies in the Language of Victorian Politics, London, 1973, pp.3, 159.

32 James M. Cahalan, Great Hatred, Little Room, The Irish Historical Novel, Cincinnati, 1983, p.xii. Cahalan opts for a collective psycho-social model of unresolved historical circumstances and tensions that fosters the rise and perpetuation of the nineteenth-century historical novel in Ireland (and Scotland), with the novel form used to explore 'current polarities' existing in society. See his chapter 'The Mythos of Modern Irish History', pp.17-42.

33 See especially the chapter 'The Famine Generation', passim, in Charles Fanning, The Irish Voice in America: Irish-American Fiction From the 1760s to the 1980s, Lexington, 1990.

34 Fanning, The Irish Voice in America, pp.75-76.

35 A selective content analysis of specifically American news or commentary is beyond the scope of the present exercise, but could provide some interesting data.

36 For example the appalling but obviously commonplace eviction described in graphic detail in 1881, 'An Extraordinary Eviction in County Louth', in NZT, 12 August 1881, p.11.

37 A perusal of any nineteenth-century year will find stories in most issues sourced to other newspapers. However, some of the larger novels are not sourced. This may indicate that a stereo-plating system may have been in operation, with the papers printing the stories from the pre-manufactured moulded plates. More research needs to be done on this topic. For an explanation of the technique see Elizabeth Morrison, 'Serial Fiction in Australian Colonial Newspapers', in John Jordan and Robert Patten (eds), Literature in the Marketplace. Nineteenth-century British Publishing and Reading Practices, Cambridge, 1995, pp.306-324; Ross Harvey, "If sufficient encouragement": Where New Zealand Newspapers got their Copy', unpublished paper presented to the Bibliographical Society of Australia and New Zealand Conference (BSANZ), 2002, pp.1-12. 
38 O'Connell is used as a touchstone for moderate nationalism in many articles over the years, as well as appearing in specific stories. See for example the lecture delivered at the Auckland Catholic Literary Society by J. A. Tole, 'Life and Times of Daniel O'Connell', in NZT, 12 August 1892, pp.12ff. \& 19 August 1892, pp.21ff; or the extensive review of a new biography of O'Connell, in NZT, 7 July 1904, pp.5-6.

39 The Reading Rooms, Land League and National League rooms can be considered local initiatives, precursors to the public library system established much later. See James H. Murphy, Catholic Fiction and Social Reality in Ireland 1873-1922, Westport, 1997, p.2, passim. Unfortunately, Pope-Hennessy does not mention fiction; 'Ireland's Favourite Reading', NZT, 25 July 1884, pp.3, 22, and NZT, 29 August 1884, pp.25-29. Despite the fact that Froude and Lecky, the two pre-eminent nineteenth-century writers on Irish history, were cited frequently in the New Zealand Tablet from 1873-1903, none of their works appears in book lists advertised in the paper. Regarding their use by the paper, see Molloy, 'Victorians, Historians and Irish History', passim. op. cit., and Heather McNamara, 'The Sole Organ of the Irish Race in New Zealand? A Social and Cultural History of the New Zealand Tablet and its Readers, 1898-1923', MA thesis, University of Auckland, 2002, pp.54-55.

40 The peaks and troughs of 'nationalist' activity can also be plotted in the editorial leader articles and general articles on news from Ireland, especially in the periods of greatest political activity and the expectation of Home Rule.

41 A New Zealand Irish attitude on the infighting of the Irish National Party can be found in the columns of NZT. The Wellington produced Catholic Times $(C T)$, after the fall of Parnell, recommended a group silence on such issues, stating the Irish should not discuss divisive events in public in New Zealand, CT 1 May 1891, p.8; see also B. McLeod, 'The New Zealand Tablet: the Moran Years', MA. thesis, Otago University, 1997, p.78. Dunedin's Bishop Moran's attitude was to stand aloof from the internal political dissension in Ireland, 'lest' it caused 'acrimonious divisions' amongst the New Zealand Irish.

42 Editorial, 'Wanted, An Irish Literary Club', in NZT, 2 April 1897, p.17, and Letter to the Editor, NZ Tablet 'The Proposed Irish Literary Club', in NZT, 9 April 1897, p.19.

43 Auckland Catholic Literary Society, 'The Life and Times of Daniell O'Connell', NZT, op. cit., and '[Charles Kickham] A Chapter of Irish History', paper read to the Dunedin Branch of the Catholic Literary Society on August 17 1892, NZT, 7 October 1892, pp.25-27, and NZT, 14 October, pp.25-27.

44 Editorial, 'Wanted, an Irish Literary Club', in NZT, 2 April 1897, p.17.

45 For example, that by John MacNeill, editor of the Gaelic Journal, 'What Ireland has Lost', NZT, 11 June 1897, p.25; [From the Boston Pilot] 'Irish Language and Literature', in NZT, 4 May 1894, p.7-8; and, on the scholarly revival of Celtic Studies, 'The Value of Celtic Study', in NZT, 22 May 1896, p.3.

46 For example, 'Gaelic Notes', in NZT, 5 April 1895, p.9.

47 'Our objects and principles', in NZT, 3 May 1873, p.8. For the Sydney Freeman's Journal see 'The Freeman's Journal. Its Past and Future', 3 November 1855, p.7.

48 NZT, ibid., p.8.

49 Editorial, 'Catholic Newspapers', in NZT, 25 August 1876, pp.10-11.

50 'An Evening with Samuel Lover', in NZT, 26 June 1875, pp.13-14 \& 'A Chapter of Irish History', in NZT, 7 October 1882, pp.25-26, \& 14 October 1882, pp.25-26; J.S.P.[?],'Review. The Poets and Poetry of Munster, in NZT, 4 July 1884, pp.14-15; and 'Review. The Parnell Movement, by T.P. O'Connor', in NZT, 18 May 1888, pp.18-19; 'A National Literature', in NZT, 18 November 1884, pp.26-27. For the historians see Molloy, 'Victorians, Historians and Irish History', pp.162-66, and McNamara, 'The Sole Organ of the Irish Race in New Zealand?', pp.54-55. 


\section{Journal of New Zealand Studies}

51 The Catholic Home Annual was published in New York by Benziger Brothers from 1884-1915. It included illustrations, coloured plates, short stories, almanac entries and journalistic pieces. While the works of Irish-American writers like Sadlier, Boyce, Halpine and Conyingham were available in New Zealand, and some of these writers had their stories serialised in New Zealand Irish-Catholic papers, their impact outside the Irish-American world it is still unclear. However, there is considerable evidence that Irish-American writers like Sadlier were regularly reprinted by publishers in Dublin and Scotland; for example, an edition of The Blakes and the Flanaghans (sic.) was printed in Dublin by Duffy \& Co., possibly as early as 1855, and a European edition of Sadlier's The Confederate Chieftains was being printed by Dunn and Wright of Glasgow for Cameron and Ferguson in Scotland and England in 1880. In addition, M.H. Gill in Dublin also reprinted works by Sadlier, see M.H. Gill, 'Publication Expense Book Two', Alice Riordan, p.72, Trinity College Dublin, Department of Early Printed Books. Additional information on some of these editions has been gleaned from antiquarian bookseller lists like those at 'abebooks.com', http://www.abebooks.com. [Accessed 6 December 2003].

52 'Address to the Irish People at Home and Abroad', in NZT, 11 February 1881, p.5.

53 Akenson also notes that the years 1867-1886 saw the Irish in New Zealand reach their largest proportion of the overall society, and the biggest proportion of the foreign born in New Zealand, see Half the World From Home. Perspectives on the Irish in New Zealand, 1860-1950, pp.40-41.

54 'The Publication of Irish Books: An Address by Sir Charles Gavan Duffy (from the Dublin Freeman)', in NZT, 23 September 1892, pp.5-6. Although reprinted by the Dublin Freeman's Journal, the address was delivered to the Irish Literary Society in London. Duffy is of course alluding to the controversy that took place, over many months, in the columns of the Dublin Freeman's Journal of 1886. The whole debate was reprinted as a sixty-page pamphlet by the Freeman's Journal in 1887; see, The Best Hundred Irish Books. Introductory and Closing Essays by "Historicus," and Letters, Dublin, 1887. Duffy's address in 1892 largely reiterates his comments in the Best Hundred Irish Books debate.

55 For the average weekly wage see the published New Zealand Statistics for the period under consideration.

56 NZT, 23 September 1892, p.7. Duffy served as first president of the Irish Literary Society, established in London in 1892 by William Butler Yeats, T.W. Rolleston and Duffy. Yeats established the National Literary Society in Dublin, also in 1892, with Douglas Hyde as first president.

57 Rev. P.E. Hurley, 'Some Reasons Why Catholics Lose the Faith in New Zealand', from the Irish Ecclesiastical Record, NZT, 15 July 1887, pp.5-6. The first instalment was published in NZT, on July 8 1887, pp.5-7.

58 The exact provenance of the Ousley and Denver series has yet to be determined.

59 [Advertisement] 'Irish Literature', in NZT, 23 November 1911, p.2381. A list of editors is given in this advertisement, as well as a list of the latest Irish writers (W.B. Yeats, Lady Gregory and Douglas Hyde).

60 The definitive work on Irish-American fiction is Charles Fanning, The Irish Voice in America. Lexington, 1999. Fanning's work is on fiction only. He does not deal with the extensive body of Irish-American poetry or drama. For Irish-American drama Fanning cites the work of Joyce Flynn, Ethnicity after Sea-Change: The Irish Tradition in Nineteenth-Century American Drama, unpublished Ph.D. dissertation, Harvard University, 1985.

61 See Appendix. For biographical details of the above, consult entries in Brown, Ireland in Fiction; the on-line Catholic Encyclopaedia (1913), http://www.newadvent.org/cathen. 
[Accessed Dec. 2002-Jan. 2003]; Robert Welch, Oxford Concise Companion to Irish Literature; Robert Hogan (ed), Dictionary of Irish Literature; Fanning, The Irish Voice in America; the on-line Princess Grace Irish Library datasets (Monaco) http://www. pgil-eirdata.org. [Accessed Dec. 2002-April 2003]; and the on-line Mary Anne Sadlier Archive, http://www.people.virginia.edu/ eas5e/Sadlier.html. [Accessed 21 January 2003].

62 However, there is no evidence they were stocked in New Zealand bookshops. For information on Cassidy see D.F. McKenzie and K.A. Coleridge (compilers), Printing, Bookselling \& Their Allied Trades in New Zealand circa 1900. Extracts from the Cyclopedia of New Zealand, Wellington, 1980. Cassidy's novels include Glenveagh; or the Victims of Vengeance (1870) which was serialised by the New Zealand Freeman's Journal in 1885; for example, see NZFJ, 25 September 1885, p.3.

63 Liz Szabo, 'Sadlier's Biography', the Mary Anne Sadlier Archive, http://www.people. virginia.edu., op. cit.

64 James Kilroy, 'Sadlier, Mary Anne', in Robert Hogan (ed.), Dictionary of Irish Literature, p.1079.

65 The Red Hand of Ulster (1850) and Willie Burke, or the Last Orphan in America (1850); see Fanning The Irish Voice in America, p.362.

66 William D. Kelly, 'A Benefactress of Her Race', in Ave Maria, 4 April 1891, p.322, reprinted in the Mary Anne Sadlier Archive. A number of other individuals also edited the paper while it was in the hands of the Sadliers.

67 Fanning, The Irish Voice in America, p.127.

68 Nicholas Evan Reid, The Bishop's Paper. A History of the Catholic Press of the Diocese of Auckland, Orewa, 2000, pp.9, 21; See also 'Irish Books for Public Libraries', in NZT, 22 April 1915, p.43.

69 Fanning, The Irish Voice in America, p.127.

70 Liz Szabo, “"My Heart Bleeds to Tell it”: Women, Domesticity and the American Ideal in Mary Anne Sadlier's "Romance of Irish Immigration", University of Virginia, 1995, p.2, in Mary Anne Sadlier Archive: http://www.people.virginia.edu. [Accessed 21 January 2003].

71 For example, labourers and domestic servants, living in ethnic enclaves like Barbados Street and the Catholic Cathedral environs of Christchurch, Green Island in Dunedin, and towards the end of the century working class Newtown in Wellington; see, Fraser, To Tara Via Holyhead, op. cit.; Thomas Bracken, in a lecture on Samuel Lover, cites Green Island in Dunedin as the home of many stereotypical Irish characters; Bernard Leslie Molloy, unpublished paper, 'Growing up in Newtown in the 1930s', typescript, in possession of the author.

72 Fraser, To Tara Via Holyhead, pp.55-56. Fraser also draws on data in Charlotte Macdonald, 'Single Women as Immigrant Settlers in NZ, 1853-1971', unpublished PhD thesis, University of Auckland, 1986; Charlotte Macdonald, A Woman of Good Character. Single Women as Immigrant Settlers in Nineteenth-Century New Zealand, Wellington, 1990, pp.106-107 \& passim. There is no mention of Sadlier's works in Macdonald.

73 Cited in James M. Cahalan, The Irish Novel, Boston, 1988, p.57.

74 See Greene, 'Literary Interactions', Irish Times Supplement, 15 March 1976.

75 Some work has been done in this area by Gillespie-Needham, see Dulcie N. GillespieNeedham, 'The Colonial and his Books. A Study of Reading in Nineteenth-Century New Zealand', PhD Thesis, Victoria University of Wellington, 1971. Heather McNamara, in 'The Sole Organ of the Irish Race in New Zealand?, also notes that miners did constitute a major component in the shareholder lists. For the shareholder lists see 'In the matter of the Companies Act, 1882 . .., The New Zealand Tablet Printing \& Publishing Co. 
Ltd., Companies Office Dunedin File,. Archives New Zealand, Dunedin Regional Office DAAB, D94/1/2961.

76 For example, Carleton's story 'Wildgoose Lodge', on the midnight burning to death of a family of thirteen, by an oath-bound secret society.

77 See Basil E. Seymour Stocker et al. (eds), Catalogue of the General Assembly Library of New Zealand, Wellington, 1897. This two-volume work and supplement lists novels by Lover, Lever, William Carleton, speeches by Daniel O'Connell, and many other Irish works.

78 Brown, Ireland in Fiction, p.221.

79 Hogan, Dictionary of Irish Literature, M-Z, pp.479-80; Robert Welch, The Oxford Concise Companion to Irish Literature, p.247.

80 Lady Georgiana Charlotte Fullerton was born in England, grew up in Paris and married Anglo-Irishman Alexander Fullerton. In 1843 Alexander Fullerton converted to Roman Catholicism, and in 1846 Georgiana Fullerton likewise converted. Fullerton wrote numerous novels that were serialised by the New Zealand Tablet. Further details are available in her entry in the on-line Catholic Encyclopaedia (1913), http://www. newadvent.org/cathen.

81 'Catholics and Public Libraries. A Suggested Reading List', in NZT, 5 February 1914, p.23.

82 As regards the Irish-American influence in New Zealand imports, the sudden demise in popularity of Irish-American fiction in New Zealand at the turn of the century needs further analysis, as more robust and accomplished Irish-American writers continued the Irish-American genre throughout the twentieth century. It is unclear whether this tail-off was due to a change in ethnicity, consumer preference, a result of international markets and pricing, or a change in business practices. The war years obviously had a major impact on the book trade and Irish emigration to New Zealand.

83 Fraser, To Tara via Holyhead. Irish Catholic Immigrants in Nineteenth-Century Christchurch, p.3.

84 For definitions of the Irish diaspora, see Donald Harman Akenson, The Irish Diaspora: A Primer, Toronto, 1993.

85 The networks include the well-established trans-Atlantic and trans-Pacific trading and communication patterns for the people of the Irish diaspora, and the literatures that maintained the communication, whether newspapers, fiction, religious or political works.

86 Dulcie N. Gillespie-Needham, 'The Colonial and His books: A Study of Reading in Nineteenth Century New Zealand', Foreword \& passim. This idea of literary homogeneity forms the basis of Gillespie-Needham's thesis.

87 Freeman's Journal (Sydney), 21 September 1859, p.1. Flanagan was a well-known Irish Catholic bookseller with premises in Market Street, Sydney.

88 For example, it should be noted that the Irish National Library (Library of Ireland) series, produced by Dublin publisher James Duffy \& Co., was specifically begun in the 1840 s to place affordable Irish national literature in the hands of those with very low incomes. It was a series readily available in New Zealand over the 1870-1900 period, and had many additional titles added over those decades.

89 For example, as McNamara notes in 'Sole Organ of the Irish Race', p.24, the literacy/ illiteracy figures used by Akenson in Half the World from Home rely on marriage register signatures only. Single persons do not form part of the analysis. 
Literature in the Irish Diaspora: The New Zealand Case, 1873-1918

\section{Appendix}

\section{Import and advertising data by author, title and first advertisement date}

The following author, title and first advertisement items have been extracted from bookshop advertisements in the New Zealand Tablet over the period 1873, the first year of the paper's publication, to 1918, the end of the World War One, and a time when the first generation of Irish immigrants to New Zealand (the gold rush and Vogel immigrants) would have been either in their old age or deceased. The bookshops include two Australian outlets that advertised extensively in the first decades of the twentieth century. A letter representing the particular bookseller advertising a work follows each first-advertisement date entry. Advertisements from the following booksellers have been used for this study:

(b) Braithwaite, Joseph, The Arcade, Dunedin

(d) Dunne, James \& E.W., George Street, Dunedin

(h) Hamilton, J.R., Book Importer, Edinburgh House, George Street, Dunedin

(L) Linehan, W.P., Wholesale and Retail Bookseller, 309 Little Collins Street, Melbourne

(G) Louis Gille \& Co., Catholic Booksellers \& Church Furnishers, 586 George St \& 75 Liverpool Street, Sydney, and 302 Lonsdale Street, Melbourne

(m) Macedo, J.A., Catholic Bookseller, Princess Street, Dunedin

(o) O'Connor, E., Catholic Book Depot, Barbadoes Street, Christchurch

(Tb) Tablet Printing Company Limited, The Octagon, Dunedin

(W) Whitaker Brothers, Lambton Quay and Cuba Street, Wellington, Boundary Street Greymouth

The following is by no means an exhaustive bibliographical listing of all nineteenth- and early twentieth-century works, from many different publishing houses in the Irish diaspora, mentioned or listed in the New Zealand Tablet.

The Appendix excludes book reviews, theological and pietistic literature, church music and serialised stories, though includes Irish Church history, and, in keeping with the tenets of late-nineteenth-century Irish cultural nationalism, the works on some Irish Saints. Non-Irish or Irish diaspora works, when not identified as having Irish authors, have been excluded. 
For reasons of clarity the numerous variant editions, noted in my data sets, have been excluded. In addition, general author entries, for example those simply listed in the New Zealand Tablet as 'works by . .. ., have also been excluded, except where there are no other entries by the author.

\section{IRISH WORKS BY GENRE, NEW ZEALAND TABLET 1873-1918}

No Author

Title

\section{Fiction}

1 Anonymous [Joyce, Robert Dwyer]

2 Anonymous, [source S.J. Browne]

3 Anonymous, [source S.J. Browne]

4 Anonymous, [source S.J. Browne]

5 Antiquary [psued.]

6 Banim, John

7 Banim, John

8 Banim, John

9 Banim, John

10 Banim, John/Michael

11 Banim, Michael

12 Banim, Michael

Bearne, David

Benziger Brothers, NY., (Publishers)

Bertholds, W.M., Mrs

Blackburne, E

Bowles, Emily

Boyce, John

Boyce, John

\section{Boyce, John}

\section{Buchanan, Robert}

Caddell, Cecilia Mary

Caddell, Cecilia Mary

Campion, J.T., Dr

Campion, J.T., Dr

Campion, J.T., Dr

[and Other Tales]
Galloping O'Hogan, or the Raparee Captains

$1875(\mathrm{~m})$

Annie Reilly, The Irish Girl

$1886(w)$

Irish Pleasantry and Fun [short stories,

includes Carleton, Lover, Lever... .]

1896 (w)

The Robber Chieftain, a Tale of Dublin Castle $1879(\mathrm{~m})$

The Mistletoe and The Shamrock, or the Chief of the North. A National Tale of the Fifth Century 1904 (G)

The Bit O'Writing and the Ace of Clubs 1886 (w)

The Denounced 1882 (o)

The Fetches $1904(\mathrm{G})$

The Boyne Water 1882 (o)

O'Hara Family: Peep-o-Day $1876(\mathrm{~m})$

O'Hara Family: Crohoore of the Billook $1876(\mathrm{~m})$

O'Hara Family: Croppy: A Tale of '98 $1876(\mathrm{~m})$

Fitz-Hern; or the Irish Patriot Chief

[or the Rover of the Irish Seas] $1875(\mathrm{~m})$

Sheer Pluck and Other Stories $1908(\mathrm{w})$

Catholic Home Annual 1900 (G)

Connor D'Arcy's Struggles 1896 (w)

Irish Tales and Sketches [A Bunch of Shamrocks.

Being a Collection of Irish Tales and Sketches] $1886(\mathrm{w})$

Irish Diamonds 1877 (m)

Mary Lee, or the Yankee in Ireland 1885 (w)

Shandy Maguire; or Tricks on Travellers.

Being a Story of the North of Ireland $1886(w)$

The Spaewife; or, the Queen's Secret. A Story

of the Reign of Elizabeth

$1885(w)$

1882 (o)

Nellie Netterville or One of the Transplanted, an Irish Catholic Tale

Wild Times, a Tale of the Times of Queen Elizabeth 1879 (w) Irish Tales $1875(\mathrm{~m})$

Last Struggles of the Irish Sea Smugglers, The $1875(\mathrm{~m})$

Michael Dwyer, the Insurgent Captain 
Literature in the Irish Diaspora: The New Zealand Case, 1873-1918

28 Carleton, William

29 Carleton, William

30 Carleton, William

31 Carleton, William

32 Carleton, William

33 Carleton, William

34 Carleton, William

35 Carleton, William

36 Carleton, William

37 Carleton, William

38 Casey, James

39 Catholic Publication Society N.Y.

40 Conyngham, David Power

41 Conyngham, David Power

42 Conyngham, David Power

43 Corkery, Daniel

44 Curtis, Robert

45 Cusack, M.F.

46 Donnelly, Eleanor (ed.)

47 Doyle, M. [M.E.T.]

48 Egan, Maurice Francis

49 Egan, Maurice Francis

50 Finn, Francis James

51 Finn, Francis James

52 Finn, Francis James

53 Fitzgerald, F.S.A.

54 Fitzgerald, Percy

55 Goldsmith, Oliver

56 Griffin, Gerald

57 Griffin, Gerald

58 Guinan, J., Rev

59 Guinan, J., Rev

60 Hall, E

61 Halpine, Charles G.

62 Halpine, Charles G.

63 Hickey, Emily

64 Hickey, P., Rev

65 Holland, Denis

66 Holland, Denis

67 Hughes, Mary, Mrs

68 Jennings, John A.
Paddy Go-Easy and his Wife Nancy

Redmond O'Hanlon

Rody the Rover

The Evil Eye, or the Black Spectre

The Irish Agent

The Poor Scholar, and other Irish Tales

Traits and Stories of the Irish Peasantry

Tubber Derg; or the Red Webb

Valentine McClutchy, the Irish Agent

Willy Reilly and his Dear Colleen Bawn

Paddy Blake's Sojourn among the Soupers

The Home Rule Candidate, and Other Stories

Rose Parnell, or the Flower of Avondale: A Tale of the Rebellion of '98

The O'Mahony, Chief of the Comeraghs: A Tale of the Rebellion of ' 98

The O'Donnells of Glen Cottage

Munster Twilight

1882 (o)

$1875(\mathrm{~m})$

1882 (o)

$1879(\mathrm{~m})$

$1879(\mathrm{~m})$

$1875(\mathrm{~m})$

$1875(\mathrm{~m})$

1875 (m)

1887 (o)

1878 (m)

1887 (w)

1886 (w)

$1885(w)$

1885 (w)

1878 (w)

1918 (G)

1886 (w)

1886 (w)

Ned Rusheen, or Who Fired the First Shot?

A Round Table of the Represntative American

Catholic Novelists, at which Is Served a Feast

of Excellent Stories

$1900(\mathrm{G})$

$1886(\mathrm{w})$

$1896(w)$

How They Worked Their Way and Other Tales

The Flower of the Flock and the Badgers of Belmont 1896 (w)
Claude Lightfoot, or How the Problem was Solved 1896 (w)

Harry Dee

$1896(w)$

Percy Wynn

$1896(w)$

Josephine's Troubles

1907 (G)

Never Forgotten

$1886(\mathrm{w})$

The Vicar of Wakefield

$1886(w)$

Card Drawing and the Half-Sir (second series

of Tales of the Munster Festivals)

$1904(\mathrm{G})$

The Invasion

$1875(\mathrm{~m})$

$1908(w)$

1906 (G)

$1889(\mathrm{w})$

$1875(\mathrm{~m})$

$1875(\mathrm{~m})$

$1908(w)$

1907 (G)

Innisfail

$1875(\mathrm{~m})$

$1878(\mathrm{~m})$

$1877(\mathrm{~m})$

Julia Ormond, or the New Settlement

$1884(d)$ 


\section{Journal of New Zealand Studies}

69 Joyce, P.W.

70 Kavanagh, M.

71 Kickham, Charles J.

72 Kickham, Charles J.

73 Lenihan, D.M.

74 Lover, Samuel

75 Lover, Samuel

76 MacKenzie, R. Shelton

77 Maher, Mrs

78 Mapother, Mary J [?]

79 Matthew, Arnold Harris (revised by W.A. Sutton, S.J., Limerick)

80 McCarthy, Justin

81 McGee, James Edward

82 McGee, James Edward

83 McHenry, [James?]

84 McHenry, James

85 McSparran, Archibald

86 Mulholland, Clara

87 Mulholland, Clara

88 Mulholland, Rosa (Lady Gilbert)

89 Mulholland, Rosa (Lady Gilbert)

90 Mulholland, Rosa (Lady Gilbert)

91 Mulholland, Rosa (Lady Gilbert)

92 Mulholland, Rosa (Lady Gilbert)

93 Mulholland, Rosa (Lady Gilbert)

94 Mulholland, Rosa (Lady Gilbert)

95 Mulholland, Rosa (Lady Gilbert)

96 Mullholland, Rosa (Lady Gilbert)

97 Murphy, James

98 Newman, M.W.

99 O’Brien, Richard Baptist (Mgr, Dean of Limerick)

100 O'Brien, Richard Baptist (Mgr, Dean of Limerick)

101 O'Brien, W., Mrs

102 O'Grady, Standish

103 O'Mara, Kathleen
Old Celtic Romances

1903 (0)

[Sheamus Dhu] The Black Pedlar of Galway, or a Tale of the Penal Times

$1886(w)$

Knocknagow, or the Homes of Tipperary

Sally Cavanagh

The Red Spy: A Story of the Land League Days

Handy Andy

Rory O'More

Bits of Blarney

The Irish Emigrant's Orphan

The Donalds [an Irish Story]

The Catholic Scholar's Introduction to English

Literature. A Text Book for the use of Catholic

Schools (with an Appendix on Irish Authors)

Maurice Tyrone (the American ed. of A Fair Saxon)

Half Hours with Irish Authors

Irish Wit and Humour: Anecdote Biography of

Swift, Curran, O'Leary and O'Connell

$1887(w)$

$1886(w)$

1915 (o)

$1877(\mathrm{~m})$

$1879(\mathrm{~m})$

$1886(w)$

$1902(\mathrm{~L})$

$1887(w)$

Irish Tales

Hearts of Steel, [or the Celt and the Saxon]

Legend of McDonnell, and the Norman De Borgos

Kathleen Mavourneen

The Miser of King's Court

A Mother of Immigrants

$1905(\mathrm{G})$

$1886(w)$

$1887(w)$

$1886(w)$

$1887(w)$

$1875(\mathrm{~m})$

$1875(\mathrm{~m})$

1903 (o)

$1887(w)$

1902 (L)

Among the Violets

1902 (L))

Gems for the Young

$1886(w))$

Marcella Grace

$1900(\mathrm{G}))$

Mrs Blake's Next-of-Kin

$1902(L))$

The Ghost of the Rath

$1902(L))$

The Marigold Series of Tales

1902 (L))

The Wild Birds of Killevy

$1886(w))$

Banshee Castle

$1896(w))$

Convict No.25: or the Clearances of Westmeath

1915 (0)

Alice Harmon, and the Mother and

her Dying Boy, by an exile of Erin

$1879(w)$

1882 (o)

Jack Hazlitt, A.M.

$1886(w)$

Rosette, a Tale of Paris and Dublin

$1908(\mathrm{G})$

The Flight of the Eagle

1908 (w)

1902 (L) 
Literature in the Irish Diaspora: The New Zealand Case, 1873-1918

104 O’Sullivan, Seamus (James Starkey)

105 O'Toole, John Esq

106 Reynolds, James

107 Roche, Kathleen

108 Rooney, Teresa J. "Elbana"

109 Russell, T. O’Neill [Reginald Tierney]

110 Sadlier, Mary Anne

111 Sadlier, Mary Anne

112 Sadlier, Mary Anne

113 Sadlier, Mary Anne

114 Sadlier, Mary Anne

115 Sadlier, Mary Anne

116 Sadlier, Mary Anne

117 Sadlier, Mary Anne

118 Sadlier, Mary Anne

119 Sadlier, Mary Anne

120 Sadlier, Mary Anne

121 Sheehan, Patrick A.

122 Sheehan, Patrick A.

123 Sheehan, Patrick A.

124 Sheehan, Patrick A.

125 Sheehan, Patrick A.

126 Sheehan, Patrick A.

127 Sheehan, Patrick A.

128 Sheehan, Patrick A.

129 Smyth, P.G.

130 Starr, S.

131 Tynan, Katherine

132
Mud and Purple

$1918(\mathrm{G})$

The O'Toole's of Ferasmalan

$1878(\mathrm{~m})$

Moses Finegan [The Adventures of

Mr Moses Finegan, an Irish Pervert]

Willie's Revenge

$1875(\mathrm{~m})$

1902 (L)

The Last Monarch of Tara, a Tale of Ireland

in the Sixth Century

$1887(w)$

$1875(\mathrm{~m})$

The Confederate Chieftains

$1886(w)$

Alice Riordan, the Blind Man's Daughter

$1896(w)$

$1886(w)$

$1886(w)$

$1886(w)$

$1886(w)$

$1876(\mathrm{~m})$

$1886(w)$

$1886(w)$

$1878(w)$

$1885(w)$

1907 (o)

1902 (L)

1907 (o)

1901 (w)

1902 (L)

1908 (G)

1915 (o)

1911 (G)

1887 (w)

1887 (w)

1914 (o)

1900 (G)

1887 (w)

1879 (m)

1896 (w)

1875 (m)

1875 (m)

$1886(w)$

$1875(\mathrm{~m})$ 


\section{Journal of New Zealand Studies}

\section{History}

140 Burke, Thomas Nicholas

Father Burke's Lectures

1882 (o)

141 Burke, Thomas Nicholas

Men and Women of Far-off Times

$1886(w)$

142 Burke, W.P.

Irish Priests in the Penal Times, 1660-1760

$1915(\mathrm{G})$

143 Cleary, Henry, W., Rev

An Impeached Nation, being A Study of

Irish Outrages

$1909(\mathrm{~Tb})$

144 Cleary, Henry, W., Rev

The Orange Society

$1897(\mathrm{G})$

145 Collins, James

Life in Old Dublin [Historical Associations of

Cook Street. Three Centuries of Dublin Printing.

Reminiscences of a Great Tribune]

1914 (o)

The Irish Brigade and Its Campaigns in the

Great American War

$1875(\mathrm{~m})$

David Power

The Irish-American Brigade and Its Campaigns

$1887(w)$

David Power

148 Corcoran, T., Rev

The Story of Clongowes Wood

1902 (L)

The Story of ' 98

1911 (L)

The Fenian Movement: Story of the

Manchester Martyrs

1911 (L)

Muckross Abbey and Innisfallen Island

(with illustrations)

$1902(L)$

152 Cullen, John B.

153 Cullen, John B.

The "Santa Croce of Ireland", or Holy Cross Abbey

(with illustrations)

$1902(L)$

The Boyne Valley: Its Antiquities and

Ecclesiastical Remains (with Illustrations) 1902 (L)

154 Cullen, John B.

155 Cullen, John B.

156 Cullen, L.M.

157 Cusack, M.F.

158 Cusack, M.F.

159 Cusack, M.F.

The Rock and Ruins of Cashel (with Illustratons)

1902 (L)

The Shannon and Its Shrines (with illustrations)

1902 (L)

The High Crosses of Ireland and the Book of Kells (with illustrations)

1902 (L)

A Patriot's History of Ireland $1878(\mathrm{~m})$

Life of St Patrick

The Liberator [The Speeches and Public Letters

of the Liberator . . . with Historical Notes] $1886(\mathrm{w})$

The Present Case of Ireland Plainly Stated 1881 (w)

The Irish Church in the Seventh and Eighth Century 1902 (L)

The Irish Church in the Sixth Century 1902 (L)

Ireland in the Days of Dean Swift 1890 (w)

Works 1887 (d)

The Curse of Cromwell 1911 (L)

The Growth of the Parish System in the Church 1902 (L)

The Irish College at Rome 1902 (L)

Contemporary Ireland. With an introduction

by T.M. Kettle

1913 (L)

1899 (d)

$1890(w)$

170 Duffy, Sir Charles Gavan

View of Irish History

$1883(\mathrm{~m})$

(Australian Edition)

172 Duffy, Sir Charles Gavan

Young Ireland: a Fragment of Irish History, 1840-1850 (Australian edition)

$1881(w)$

173 Ferguson,

The Story of the Irish Before the Conquest

$1890(w)$ Mary Catherine (Lady) 
Literature in the Irish Diaspora: The New Zealand Case, 1873-1918

174 Fitzpatrick, W.J.

175 Fitzpatrick, William John

176 Flanagan, Roderick

177 French, Nicholas, Dr

178 George, Henry

179 Glynn, J.A.

180 Gregg, William Stephenson (pseud.)

181 Haverty, Martin

182 Healy, Dr, Rev

183 Healy, Dr, Rev

184 Healy, Dr, Rev

185 Healy, Dr, Rev

186 Healy, Dr, Rev

187 Heinrich, Hugh

188 Higgins, Dr, Rev

189 Hogan, James Francis

190 Hopkins, Tighe

191 Hull, Eleanor

192 Keating, Geoffrey

193 Kelly, M., Rev, DD

194 Kelly, R.J.

195 Kelly, Rev

196 Lenihan, Maurice

197 Lingard, John

198 Lingard, John

199 MacDonagh, Michael

200 MacDonald, John

201 MacGee, James E.

202 MacNeill, J.G.S.

203 MacNevin, Thomas

204 Madden, Richard Robert Dr

205 Maguire, John Francis

206 Malone, Sylvester

207 McCarthy, John G.

208 McCarthy, Justin

209 McCarthy, Justin

210 McCarthy, Justin
Life, Times, and Correspondence of the

Right Rev. Dr. Doyle, 2 vols.

$1887(w)$

Ireland Before the Union with extracts

from the unpublished diary of John Scott LLD

of Clonmel, First Chief Justice of the

King's Bench 1774-1798

1882 (o)

The Aborigines of Australia

Historical Works of Dr French, 2 vols.

$1905(\mathrm{G})$

$1878(\mathrm{~m})$

1899 (d)

1902 (L)

The Irish Brigade

Irish History for English Readers

[ . . . from the Earliest Times to the

Close of the Year 1885]

1899 (d)

History of Ireland Ancient and Modern

Maynooth College

The Four Masters

The Round Towers and the Holy Wells of Ireland

Some Irish Graves in Rome

$1873(\mathrm{~m})$

1902 (L)

1902 (L)

1902 (L)

$1902(\mathrm{~L})$

Tara, Pagan and Christian

1902 (L)

The Irish in England and Scotland

1911 (L)

The Catholic Church in Ireland in the

Nineteenth Century

1902 (L)

The Irish in Australia

1899 (d)

1899 (d)

$1909(\mathrm{G})$

$1873(\mathrm{~m})$

$1878(\mathrm{~m})$

$1902(\mathrm{~L})$

1902 (L)

An Abbeytown of Ireland

Limerick, its History and Antiquities, Ecclesiastical, Civil and Military, from the Earliest Ages

$1887(w)$

History of England (abridged)

1881 (o)

History of England 10 vols.

[revised \& enlarged,covering Ireland] 1877 (m)

The Irish on the Somme

$1918(\mathrm{G})$

The Diary of the Parnell Commission

[Revised from the Daily News]

1890 (о)

The Men of '48, W.S. O'Brien, Charles G. Duffy,

Thomas Davis, John Mitchel, and their Co-patriots

[The Men of '48. Being a Brief History of the

Repeal Association and the Irish Confederation] 1886 (w)

The Irish Parliament, What it was, and what it did 1887 (w)

The Confiscation of Ulster

$1878(\mathrm{~m})$

Literary Remains of the United Irishmen of $1798 \quad 1887$ (o)

The Irish in America 1911 (L)

Irish Church History [Church History of Ireland] 1876 (m)

Henry Grattan, A Historical Study

$1886(\mathrm{w})$

1881 (o)

$1886(w)$

1899 (d) 


\section{Journal of New Zealand Studies}

211 McCarthy, Justin

212 McCarthy, Justin H.

213 McGee, James Edward

214 McGee, James Edward

215 McGee, Thomas D'Arcy

216 McKenna, J.E., Rev, MRIA.

217 McMahon, Ella, Mrs (Trans.)

218 Meehan, Charles Patrick, MRIA.

219 Meehan, Charles Patrick, MRIA.

220 Meehan, Charles Patrick, MRIA.

221 Meehan, Charles Patrick, MRIA.

222 Mitchel, John

223 Mitchel, John

224 Mitchel, John

225 Mitchel, John

226 Moran, Patrick Rev Dr

227 Moran, Patrick Rev Dr

228 Moran, Patrick Rev Dr

229 Murphy, Denis, Rev S.J.

230 O'Byrne, M.L.

231 O'Callaghan, James Cornelius

232 O'Connell, Daniel

233 O'Connor, T.P.

234 O'Connor, T.P., Mrs

235 O'Doherty, Dr, Rev.

236 O'Doherty, J.K., Rev.

237 O'Donnell, J.F.

238 O'Hanagan, J.R.

239 O'Laverty, J., Rev. MRIA

240 O'Neill Daunt, W.J., Esq

241 O'Neill Daunt, W.J., Esq

242 O'Rourke, John Rev

243 Peraud, Adolphe Louis

244 Redmond, John

245 Reynolds, John J.
The Stirring Incidents of Irish History

$1887(w)$

Outline of Irish History, by Justin H. McCarthy

(son of Justin McCarthy, MP)

$1884(d)$

Celebrated Sons of Irishmen

[Lives of Irishmen's Sons and their Descendents] 1886 (w)

Sketches of Irish Soldiers in Every Land

$1886(w)$

History of Ireland

Lough Derg; Ireland's National Pilgrimage (Illustrated) 1902 (L)

Irish Faith in America, Recollections of a

Missionary Translated from the French by

Mrs Ella MaMahon

$1887(w)$

Rory O'Donnell, Earl of Tryconnell

(enlarged edition with notes)

$1876(\mathrm{~m})$

The Fate and Fortunes of Hugh O'Neill,

Earl of Tyrone (enlarged ed. with notes)

$1876(\mathrm{~m})$

The Rise and Fall of the Irish Franciscan

Monasteries, and Memoirs of the Irish Hierarchy

in the Seventeenth Century

1887 (0)

History of the Geraldines [The Geraldines,

Earls of Desmond, and the Persecution of the Irish Catholics]

History of Ireland

Ireland Since '98

Jail Journal

The Last Conquest of Ireland, Perhaps

The Civilisation of Ireland before the

Anglo-Norman Invasion

Essays on the Early Irish Church

The Priests and People of Ireland - A Vindication

$1896(w)$

$1886(w)$

$1875(\mathrm{~m})$

$1876(\mathrm{~m})$

$1886(w)$

$1902(\mathrm{~L})$

$1878(\mathrm{~m})$

1905 (L)

$1887(w)$

$1887(w)$

Art MacMurrough O'Kavanagh, Prince of Leinster

History of the Irish Brigades in the

Service of France

$1875(\mathrm{~m})$

Memoir on Ireland, Native and Saxon

$1875(\mathrm{~m})$

1890 (o)

$1918(\mathrm{G})$

1902 (L)

1902 (L)

$1878(\mathrm{~m})$

$1887(w)$

1911 (L)

$1878(\mathrm{~m})$

1882 (o)

History of Ireland

History of the Great Irish Famine of 1847, with notices of earlier Famines

1882 (o)

Ireland Under English Rule

$1877(\mathrm{~m})$

1907 (G)

1903 (о) 
Literature in the Irish Diaspora: The New Zealand Case, 1873-1918

246 Rutherford, John

247 Sheil, Richard Lalor

248 Spalding, Bishop

249 Sullivan, A.M.

250 Sullivan, A.M. \& T.D.

251 Sullivan, A.M., MP.

252 Sullivan, T.D.

253 Sullivan, T.D.

254 Teeling, C.H.

255 Thebaud, Augustine J.

256 Walsh, E., Rev.

257 Wright, Thomas

\section{Biography}

258 Anonymous, A Priest

259 Bannon, John

260 Bourke, Ulick J.

261 Burke, John

262 Cashman, D.B.

263 Cashman, D.B.

264 Curry, J., Rev

265 Cusack, M.F. (Nun of Kenmare)

266 Cusack, M.F. (Nun of Kenmare)

267 Cusack, M.F. (Nun of Kenmare)

268 Donard, Slieve

269 Emmet, Thomas Addis

270 Fitzpatrick, W.J.

271 Fitzpatrick, W.J.

272 Hand, John

273 Kelly, J.F.

274 Luby, Thomas Clarke

275 Lyon, Captain

276 MacDevitt, John

277 MacDonagh, Michael

278 Madden, Richard

279 Maguire, John Francis

280 McGee, James Edward

281 Mitchel, John
The Fenian Conspiracy [The Secret History of the Fenian Conspiracy: Its Origin, Objects, and Ramifications]

1886 (d)

Sketches of the Irish Bar

$1886(w)$

Religious Mission of the Irish People and

Catholic Colonisation

$1887(w)$

The New Ireland

$1883(w)$

Irish Readings

1903 (o)

The Story of Ireland (illustrated)

$1877(\mathrm{~m})$

1886 (d)

$1875(\mathrm{~m})$

$1886(w)$

$1886(w)$

1902 (L)

by Rev. Dr. Donnelly)

The History of Ireland: From the Earliest Period of Irish Annals to the Present Time

$1873(\mathrm{~m})$

Life of John Murphy, Priest and Patriot

$1883(w)$

John Mitchel

1911 (L)

The Life and Times of the Most Rev. John MacHale

1904 (o)

Life of Robert Emmet

1903 (o)

Life of Michael Davitt

$1904(\mathrm{G})$

Life of Michael Davitt (with speeches)

$1896(d)$

O'Connell

1902 (L)

The Liberator; Memoir of Daniel O'Connell

(illustrated)

$1880(w)$

The Life of Daniel O'Connell, the Liberator. His

Times - Political, Social and Religious (Art volume with 32 full page steel engravings of portraits...) 1900 (G)

The Life of Father Mathew, the People's

Soggarth Aroon

$1879(w)$

Daniel O'Connell

1911 (L)

Memoir of Thomas Addis and Robert Emmet, 2 vols. 1915 (G)

Life and Times of Lord Cloncurry

$1876(\mathrm{~m})$

$1886(w)$

$1911(\mathrm{~L})$

$1878(\mathrm{~m})$

Illustrious Irish Exiles

Life and Times of Daniel O'Connell

[Daniel O'Connell and His Day]

$1876(\mathrm{~m})$

$1875(\mathrm{~m})$

1902 (L)

$1904(w)$

1911 (L)

$1902(L)$

Father Mathew: His Life and Work

The Glories of Ireland: Lives, Works and

Achievements of Ireland's greatest Priests, Poets,

Patriots, Statesmen, Wits and Soldiers, illustrated

$1887(w)$

Life and Times of Hugh O'Neill 


\section{Journal of New Zealand Studies}

282 Moore, Thomas

283 Moran, Patrick

284 Moran, Patrick

285 O'Brien, Richard Barry

286 O'Connor, Thomas Power

287 O'Rourke, John Rev

288 Ryan, W.P.

289 Ryan, W.P.

290 Stewart, Agnes

291 Taylor, Ida

292 Tone, W.T.W. (ed.)

293 [Atkinson, Mrs?]

\section{Language}

294 Bourke, Ulick J. Canon

295 Dowling, [E. \& B.?]

296 Hayden, William

297 Joyce, P. W.

298 Joyce, P. W.

299 Nolan, John Rev

300 O'Daly, John

301 O'Growney, Eugene

302 O'Growney, Eugene

303 O'Reilly, Edward

304 Society for the Preservation of the Irish Language

305 Society for the Preservation of the Irish Language

306 Society for the Preservation of the Irish Language

\section{Music}

310 Barry, M.J. Esq

311 Dollard, J.B., Rev

312 Ellis, Hercules
Life and Times of Lord Edward Fitzgerald [Life and

Death of Lord Edward Fitzgerald]

$1887(w)$

History of the Catholic Archbishops of Dublin

since the Reformation

$1876(\mathrm{~m})$

The Life of the Most Rev. Oliver Plunket

[Memoirs of the Most Rev.]

1887 (w)

The Life of Charles Stewart Parnell

$1904(\mathrm{G})$

The Life of Charles Stewart Parnell [The Parnell

Movement with a Sketch of Irish Parties, from 1843] 1905 (G)

Life of O'Connell

$1878(\mathrm{~m})$

John Boyle O'Reilly 1911 (L)

Thomas Davis 1911 (L)

The Life and Letters of Sir Thomas More (illustrated) $1886(w)$

Life of Lord Edward Fitzgerald

1885 (d)

Life and Adventures of Theobald Wolfe Tone

1899 (d)

St. Brigid, Abbess of Kildare, and other Essays 1907 (G)

Easy Lessons in Irish [Easy Lessons: or,

Self Instruction in Irish]

$1883(w)$

Dowling's Irish and English Catechism

$1885(w)$

Introduction to the Study of the Irish Language

$1905(\mathrm{G})$

[Based upon the Preface to Dunlevy's Catechism]

Irish Grammer

$1905(\mathrm{G})$

Irish Music and Song (set to music)

$1905(\mathrm{G})$

Irish Grammar Rules, in Prose and Verse

$1883(w)$

Self-Instruction in Irish, with Easy Lessons

for Beginners

$1883(w)$

Simple Lessons in Irish. Parts 1 \& 2

[Giving Pronounciation of Each Word]

$1905(\mathrm{G})$

Simple Lessons in Irish. Parts 3, 4, 5

[Giving Pronounciation of Each Word]

$1905(G)$

Irish-English Dictionary (sic.) [Containing Upwards

of Twenty-thousand Words . . . Irish Grammar] 1905 (G)

First Irish Book

$1885(w)$

Second Irish Book

$1885(w)$

Third Irish Book

$1886(w)$

Irish Copy Book

$1885(w)$

Irish Grammar Rules

$1885(w)$

Moore's Melodies (In Irish)
The Songs of Ireland

Irish Lyrics and Ballads

The Songs of Ireland $1875(\mathrm{~m})$

$1918(\mathrm{G})$

$1876(\mathrm{~m})$ 
Literature in the Irish Diaspora: The New Zealand Case, 1873-1918

313 Fahy, T.A.

314 Glover, Prof (ed.)

315 Hays, Edward

316 McCarthy, Denis F.

317 Molloy, James Lynam [?]

318 Moore, Thomas

319 Moore, Thomas

320 Moore, Thomas

321 Moore, Thomas

322 Rooney, Hubert E.

323 Sullivan, T.D.

324

325

326

327

328

329

330

331

332

333

334

335

336

337

338

339

340

\section{Oratory}

341 [Anonymous]

342 Burke, J. (ed.)

343 Davis, Thomas (ed.)

344 Hoey, J.C. (ed.)

345 MacNevin, T. (ed.)

346 Madden, Daniel Owen (ed.)

347 O'Connell, John (ed.)

348 Sullivan, A.M., MP.

349 Sullivan, T.D.
Irish Songs and Poems

$1889(w)$

Moore's Irish Melodies with symphonies and accompaniments by Sir John Stevenson, edited by

Professor Glover and set to music by him (gilt bound) 1876 (m)

The Ballads of Ireland (2 vols., illustrated) 1882 (o)

The Book of Irish Ballads

$1875(\mathrm{~m})$

$1889(\mathrm{w})$

$1873(\mathrm{~m})$

Irish Melodies (with music) /gilt cloth

Irish Melodies, with the accompaniment of Sir John

Stevenson and Sir Henry Bishop (handsomely bound) 1890 (w)

Moore's Irish Melodies

$1886(w)$

Moore's Irish Melodies, with Piano Accompaniment 1883 (w)

The Well-known Songs of Ireland (comprising forty

popular Irish songs with full music score and words) 1905 (G)

National Songs (4 nos.)

$1889(\mathrm{w})$

Ballads, Popular Poetry, and Household Songs

of Ireland

$1887(w)$

Cruiskeen Song Book

Cushla Machree Song Book

$1889(w)$

$1889(w)$

Davitt Song Book

$1889(w)$

$1889(w)$

$1889(\mathrm{w})$

$1875(\mathrm{~m})$

$1889(\mathrm{w})$

$1889(w)$

$1875(\mathrm{~m})$

$1887(w)$

$1887(w)$

$1889(w)$

$1889(w)$

$1889(w)$

$1875(\mathrm{~m})$

$1887(w)$
Sunburst of Ireland Reciter [ . . . A Selection of the Most Celebrated Addresses Delivered by Irish Orators and Patriots at the Bar]

$1875(\mathrm{~m})$

$1873(\mathrm{~m})$

$1873(\mathrm{~m})$

$1873(\mathrm{~m})$

$1873(\mathrm{~m})$

$1873(\mathrm{~m})$

$1873(\mathrm{~m})$

O'Connell's Speeches (2 vols.)

$1881(w)$

Patrick Egan, Treasurer to the Land League

[Guilty or Not Guilty] Speeches from the Dock, or Protests of Irish Patriotism.
1899 (d) 


Poetry
350 Bracken, Thomas
351 Davis, Thomas
352 Davis, Thomas (ed.)
353 Duffy,
Sir Charles Gavan (ed.)
354 Ferguson, Samuel
355 Fitzschary, J.C.
356 Flanagan, Roderick
357 Godler, F., Rev
358 Griffin, Gerald
359 Hogan, Michael
360 Keegan, John
361 Lover, Samuel
362 Mangan, James Clarence
363 McCarthy, Denis Florence
364 Meehan, C.P. Rev, MRIA

365 Mitchel, John (ed.)

366 Moore, Thomas

367 Moore, Thomas

368 O'Connor, Ruth

369 O'Rielly, John Boyle

370 O'Rielly, John Boyle

371 Russell, Matthew, Rev

372 Speranza [Mrs Jane Francesca Wilde]

373 Sullivan, A.M.

374 Sullivan, T.D.

375 Sullivan, T.D.

376 Sullivan, T.D.

377 Tynan, Katherine

378 Upton, W.C.

\section{Memoir}

379 [A Country Curate]

380 Barrington, Jonah

381 Brophy, Michael

382 O'Brien, Barry

383 O'Brien, Sophie, Mrs

384 O'Reilly, John Boyle

385 Sullivan, A.M.

386 Walsh, John Edward
Behind the Tomb and Other Poems

$1873(b)$

National Ballads, Songs and Poems

$1875(\mathrm{~m})$

The Spirit of the Nation

The Ballad Poetry of Ireland

The Poetry of Sir Samuel Ferguson

The Bridal of Drimna and other Poems

Australian and Other Poems

St. Columba and other Poems

Poems

Lays and Legends of Thomond

Legends and Poems

Poems of Ireland

Poems

Poems

The Poets and Poetry of Munster. A Selection of Irish Songs in the Original Irish Language, with

Poetical Translations, into English by James

Clarance Mangan, and Biographical Sketches

1883 (d)

Poems, by James Clarence Mangan, with

Biographical Introduction by John Mitchel

Lalla Rookh

Poetical Works (assorted bindings)

Wild Flowers

In Bohemia, Poems by John Boyle O'Rielly

The Statues in the Block and Other Poems

Rose Kavanagh and Her Verses

Poems

Poems

Green Leaves, A Volume of Irish Verses

Poems

Prison Poems, or Lays of Tullamore

Rhymed Life of St. Patrick

Cuchulain, the Story of His Combats at the Ford,

a Dramatic Poem

$1875(\mathrm{~m})$

$1875(\mathrm{~m})$

1887 (o)

$1887(\mathrm{w})$

1905 (G)

$1887(w)$

$1886(w)$

$1889(w)$

$1908(w)$

1890 (o)

$1886(w)$

$1887(w)$

$1887(w)$

$1886(w)$

1896 (d)

$1886(w)$

$1886(w)$

$1887(w)$

$1910(\mathrm{~Tb})$

1877 (m)

$1875(\mathrm{~m})$

$1889(\mathrm{w})$

$1877(\mathrm{~m})$

$1889(\mathrm{w})$

1907 (G)

$1890(w)$

Sketches in an Irish Parish

1902 (L)

1887 (o)

1887 (w)

Sketches of the Royal Irish Constabulary

1905 (L)

1905 (L)

Under Croagh Patrick

Watchwords from John Boyle O'Reilly (with a

Critical and Biographical Preface by

Katherine E. Conway

$1896(w)$

1899 (d)

1904 (G) 
Literature in the Irish Diaspora: The New Zealand Case, 1873-1918

\section{Criticism}

387 Black, Chauncey F.

Essays and Speeches of Jeremiah (John) Sullivan

Black (Judge), with a Biographical Sketch by

Chauncey F. Black

$1887(w)$

388 Burke, Edmund

On Irish Affairs

389 Burke,

Thomas Nicholas

[Lectures on] Faith and Fatherland

$1886(w)$

1903 (o)

390 Burke,

Refutation of Froude

$1875(\mathrm{~m})$

Thomas Nicholas

391 Callaghan, J.C.

The Irish at Home and Abroad

$1875(\mathrm{~m})$

Advice to Irish Girls in America

$1886(w)$

Essays and Ballads

$1889(w)$

Ireland's Appeal to America

1911 (L)

Anglo-Irish Essays

$1918(\mathrm{G})$

Around the World with Irish Delegates

1899 (d)

Irish Essays

1909 (G)

$1886(w)$

$1887(w)$

399 O'Neill Daunt, W.J., Esq Essays on Ireland

400 Weekly Freeman's Journal Triumph of Law and Order in Ireland (illustrated)

[Scenes from the Triumph of 'Law and Order' in Ireland under the Last and Worst Coercion Act as Administered by 'the brave Mr. Balfour.'

1890 (o)

401

Irish Priests and Poets

$1886(w)$

402

Trinity College No Place for Catholics

$1902(\mathrm{~L})$

\section{Other}

403 Bracken, Thomas

Paddy Murphy's Budget. A Humourous

Epitome of Political Events for the

1880

Past Five Years

(all stores)

Butler's Lives of the Saints

1904 (o)

St. Columb-Kille: His Life and Labours

1902 (L)

Sketches in Carbery, Co. Cork, Its Antiquities,

History, Legends and Topography

$1887(w)$

407 Finnerty, John F.

Ireland in Pictures [Ireland in Pictures: A Grand

Collection of over 400 Magnificent Photographs of the Green Isle . . . with Historical and Descriptive

Sketches by the Hon. John F. Finnerty of Chicago] 1911 (L)

408 Gladstone, W.E.

Handbook of Home Rule

1899 (d)

408 Kettle, T. M.

The Open Secret of Ireland, with an introduction by John Redmond, MP.

$1912(\mathrm{~L})$

410 Leahy, E.

St Grellan (an Irish Saint), Patron of Hy-Maine

1902 (L)

The Book of Irish Readings in Prose and Verse:

From the Works of Popular Irish Authors

$1883(w)$

English Interference with Irish Industries

$1887(w)$

413 Melusine

The Irish Birthday Book (bound in Irish linen)

pseud. Emily Skeffington Thompson

414 Miller, James

.... Selections from the Speeches and Writings of Irish Men and Women . . . Arranged by Melusine] 1887 (w)

Reference Book of Ireland, containing Complete List of Places and Populations, Provinces, Counties, Baronies ... Compiled from the Latest Statistics by James Miller 


\section{Journal of New Zealand Studies}

415 Moore, Thomas

416 Nation Newspaper, The

417 O'Doherty, Dr, Rev

418 O'Doherty, Dr, Rev

419 O'Mahoney, Michael

420 O'Riordan, M., Rev

421 Savage, John, LLD

422 Shorsa, May

423 Wilkinson, H. Spencer

424 Winter, S.V. [publisher, Melbourne]

425

426

427 [Anonymous]
Travels in Search of a Religion (with notes and illustrations, by Thomas Moore) 1878 (m)

A Record of Traitorism (reprinted from the Nation) 1899 (d) St. Eugene of Ardstraw 1902 (L) The Martyred Bishop of Derry 1902 (L)

St. Columbcille 1911 (L)

St. Finian of Moville

1902 (L)

Picturesque Ireland, A Literary and Artistic Delineation of the Natural Scenery, Remarkable Places, Historical Antiquities, Public Buildings, Ancient Abbeys, Ruins, Towers, Castles, and other Romantic and Attractive Features of Ireland...

$1878(\mathrm{~m})$

Love Letters of a Fenian

1903 (o)

The Eve of Home Rule

$1886(\mathrm{w})$

Irish Australian Almanac and Directory 1875 (m)

Irish Architecture and Antiquities

1911 (L)

1878 (h)

Scenery of Ireland

$1911(\mathrm{~L})$ 